\title{
MARK(ET)ING NONDISCRIMINATION: PRIVATIZING ENDA WITH A CERTIFICATION MARK
}

\author{
Ian Ayres* \\ Jennifer Gerarda Brown**
}

TABLE OF CONTENTS

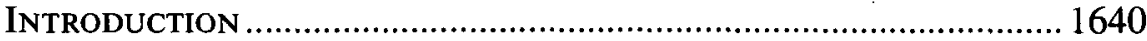

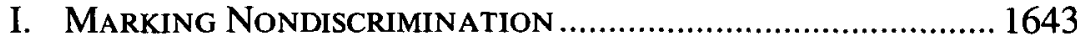

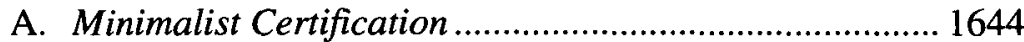

B. Third-Party Beneficiaries ................................................ 1645

C. The Benefits of Privatizing ENDA .................................. 1646

1. Amelioration ........................................................... 1647

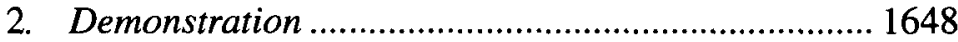

3. Realignment .......................................................... 1650

II. TAILORING THE Coverage of THE

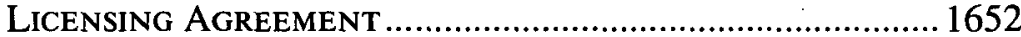

A. Gender Identity and Expression ..................................... 1657

B. Healthcare Coverage.................................................... 1659

C. More Expansive Measures of Gay Friendliness .............. 1660

D. Covering Affiliate Corporations...................................... 1665

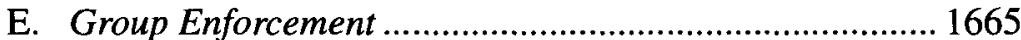

III. MARKETING NoNDISCRIMINATION ..................................... 1669

A. The Incremental Costs.................................................... 1669

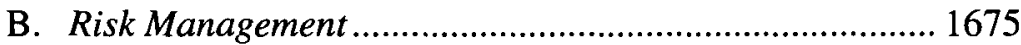

C. Satisfying Input Demand ................................................... 1676

D. Additional Consumer Demand ........................................ 1679

1. Government Contractor Ordinances ....................... 1680

2. The Impact on Demand in a World of "Acoustic Separation"................................................ 1681

3. The Impact on Demand: Boycotts............................. 1684

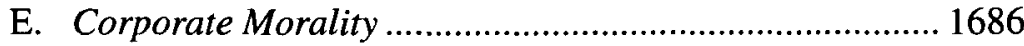

IV. RESPONDING TO CRITICISMS............................................. 1688

* William K. Townsend Professor of Law, Yale Law School. B.A. 1981, J.D. 1986, Yale; Ph.D. (Economics) 1988, Massachusetts Institute of Technology.

** Professor, Quinnipiac University School of Law; Senior Research Scholar and Director, Workshop on Dispute Resolution, Yale Law School. B.A. 1982, Bryn Mawr; J.D. 1985, University of Illinois. -Ed. Jeremy Bishop, Paul Breloff, William Eskridge, Richard Gora, Daryl Herrschaft, Gowri Ramachandran, Catherine Rogers, Tom Sylvester, and seminar participants at Boston University, Columbia, and University of Missouri-Columbia law schools provided helpful comments. 
A. Reducing Demand for a Statutory Prohibition................ 1688

B. Contingent Demand for a Statutory Prohibition .............. 1690

C. Commodifying Equality................................................ 1691

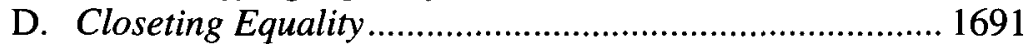

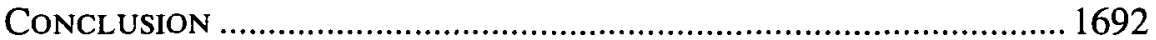

\section{INTRODUCTION}

People in the United States strongly support the simple idea that employers should not discriminate against gays and lesbians. In a 2003 Gallup poll, eighty-eight percent of respondents said that "homosexuals should ... have equal rights in terms of job opportunities."' Even prominent social conservatives-such as George W. Bush-give lip service to the idea that employment discrimination on the basis of sexual orientation is wrong. ${ }^{2}$

But gay rights advocates have achieved only modest legal reform on this issue. Seventeen states have prohibited employment discrimination against gays and lesbians. ${ }^{3}$ A seemingly modest bill, the Employment NonDiscrimination Act (ENDA), which only prohibits disparate treatment on the basis of sexual orientation, has been introduced several times in Congress, always without success. ${ }^{4}$ ENDA has little chance of passing during the Bush administration unless midterm elections in 2006 radically change the face of Congress. ${ }^{5}$ Civil rights advocates may even abandon ENDA and

1. George Gallup, Jr., The Gallup Poll: Public Opinion 2003, at 162 (2004); see also Los Angeles Times Poll Alert: Selected Results from the Times Poll, Gay Issues Survey 16 (Mar. 27-30, 2004), http://www.latimesinteractive.com/pdfarchive/nationworld/la-poll041104pdf.pdf (showing that seventy-two percent "favor ... laws to protect gays against job discrimination").

2. When asked whether he thought that gays and lesbians should have the same rights as other Americans, Bush said, "Yes. I don't think they ought to have special rights, but I think they ought to have the same rights." He subsequently denied knowing "the particulars" of the Employment Non-Discrimination Act (ENDA), and so avoided saying whether or not he would support it, but did claim to be "the kind of person-I don't hire or fire somebody based upon their sexual orientation ... . I support equal rights but not special rights for people." When asked to define "special rights," Bush said, "Well, it'd be if they're given special protective status." Online NewsHour: The Second Presidential Debate (Oct. 11, 2000), http://www.pbs.org/newshour/bb/election/2000debates/ 2ndebate3.html (last visited Apr. 15, 2005).

3. Cal. Gov't Code $\$ 12940$ (West 2004); Conn. Gen. Stat. AnN. \$ 46a-81c (West 2004); Haw. Rev. Stat. \& 378-2 (2004); 775 Ill. Comp. Stat. 5/1-102 (2006); ME. Rev. Stat. AnN. tit. 5, § 4572 (2005); Md. Code AnN., Lab. \& Empl. 49B § 16 (LexisNexis 2005); Mass. Gen. Laws ch. 151B, § 4 (2004); Minn. Stat. ANn. §363A.08 (West 2005); Nev. Rev. Stat. $\$ 613.330$ (LexisNexis 2005); N.H. Rev. StaT. AnN. \$ 354-A:7 (2005); N.J. STAT. ANN. 10:5-12 (West 2002 \& Supp. 2005); N.M. STAT. § 28-1-7 (2005); N.Y. ExEC. LaW § 296 (McKinney 2005); Or. Rev. Stat. § 659A.030 (2003); R.I. Gen. LaWs § 28-5-7 (2004); Vt. Stat. ANN. tit. 21, § 495 (2005).

4. See infra Part II.

5. President Clinton signed an executive order that prohibited discrimination on the basis of sexual orientation in employment within the federal civilian workforce. Exec. Order No. 13,087, 63 Fed. Reg. 30,097 (May 28, 1998). George W. Bush left this executive order intact when he assumed office. Despite some uncertainty created by the Bush Administration Office of Special Counsel, the policy of nondiscrimination appears to remain in force. Civilrights.org, Under Pressure, Bush Appointee Restores GLBT Anti-Discrimination Information (Apr. 23, 2004), http:// www.civilrights.org/issues/glbt/details.cfm?id=22558. 
instead promote a broader, omnibus civil rights improvement act, in which employment rights for gays would presumably play a part.

This Article attempts to extend ENDA rights to individual employees by another means. The certification mark, a little-known piece of intellectual property, provides a mechanism for employers to commit to the exact substantive duties of ENDA. We have created a symbol, an $F E$ inside a circle, that we call the "Fair Employment" mark.

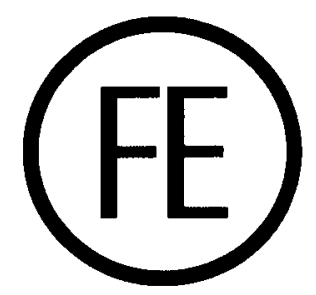

We have formally applied to the United States Patent and Trademark Office to register this symbol as a certification mark, which we would own. ${ }^{6}$

The idea behind the Fair Employment mark is simple, really: by entering into the licensing agreement with us, an employer gains the right (but not the obligation) to use the mark and in return promises to abide by the wordfor-word strictures of ENDA. Displaying the mark signals to knowing consumers and employees that the company manufacturing the product or providing the service has committed itself not to discriminate on the basis of sexual orientation.

Other certification marks (such as the Good Housekeeping Seal and the Underwriters Laboratory and Orthodox Union marks) require the mark holder to police licensees to insure compliance with the requirements of the licensing agreement. But the licensing agreement for the Fair Employment mark allows employees and applicants to enforce the ENDA duties directly as express third-party beneficiaries of the agreement. ${ }^{7}$ The Fair Employment mark thus replicates the core enforcement mechanism of ENDA by creating private causes of action in the same class of individuals who would gain protection under the statute.

The mark represents an incremental strategy in the struggle for equality. Most importantly, the mark holds out the possibility of extending substantive ENDA rights-especially rights to sue for discrimination-to potentially hundreds of thousands of workers and applicants who are currently uncovered.

But the mark also provides a "demonstration" effect. It provides members of Congress with information that might quell concerns about whether they should support ENDA. The mark provides a mechanism for producing quasi-binding precedent about a statute before the statute is ever enacted.

6. Office of Patents \& Trademarks, Certification Mark Application Receipt (Feb. 17, 2005) (copy on file with author).

7. A draft of the licensing agreement is on file with the authors and is included in the Appendix. See app. 
The mark thus provides legislators with information about the ways a statute might be interpreted by courts, as well as the rates of litigation the statute might generate.

Of course, these benefits of the mark will only accrue if employers actually sign the license agreement. Ay, there's the rub. "No employer in her right mind would volunteer to be a defendant in a lawsuit," our gentle readers might reasonably protest. We appreciate this concern and devote a fair amount of space in this Article to argue that employers could rationally volunteer for potential liability.

Of the reasons employers might make themselves vulnerable, the most important is that "practicing" the mark might induce more sales. The mark provides another way supporters of gay rights can vote with their wallets, rewarding progressive policies and institutions. Just as consumers can travel and spend tourism dollars to support progressive state and local governments, so, too, they can reward companies that treat gay employees fairly, by purchasing their products and services.

The mark might also help recruit employees and appease other input suppliers. Some employers might see little downside to signing the license agreement because their employees already have private rights of action under state law or local ordinance. Importantly (and at first blush somewhat paradoxically), some employers might sign to contain discrimination liability since the licensing agreement mirrors ENDA's limitations on certain aspects of liability (for example, the 180-day filing requirement and no disparate impact liability). Some firms might prefer to make discrimination liability subject to the specific terms of a contract rather than the expansive (and general) terms of an employee handbook. Still others may sign just because it is the right thing to do.

Many, many employers have already included sexual orientation in nondiscrimination policies contained in employee handbooks. Employers often use their nondiscrimination policies to recruit employees and appease customers, but during litigation some employers argue that an employee handbook does not constitute a promise not to discriminate. "At will" employment regimes in some states do not recognize employee handbooks as constraining employers' right to fire for any reason-including an employee's sexual orientation. By signing the license, an employer effectively waives this possible defense.

The Article is divided into four parts. Part I describes the law of certification marks and the potential benefits of the Fair Employment mark as a new type of federalism. Part II digs into the details of the licensing agreement and defends the drafting choices that we made in tailoring the duties of licensees. Part III identifies employers that we predict would sign the mark - even in the face of potential boycotts and legal liability. Finally, Part IV takes on concerns about whether adoption of the mark will actually further the greater goal of equality. 


\section{MARKING NONDISCRIMINATION}

Certification marks are used to signal that a product or service bearing the mark has met a specific standard set forth by the mark's owner, the licensor. Groups or individuals can register certification marks with the federal government much as we do trademarks. ${ }^{8}$ But certification marks are a distinct type of intellectual property because they are the only piece of IP that owners cannot "practice" themselves.

A trademark owner must be involved in producing the item or providing the service that bears the mark. ${ }^{9}$ A certification mark owner, in contrast, must remain independent and may not produce any of the goods or services to which the mark applies. ${ }^{10}$ Owners of certification marks cannot use the mark on any product that they manufacture. Only licensees are allowed to use the mark. The owner's job is to certify that the licensees conform to requirements of the license so that the public can trust the quality or integrity of the product and its manufacturer. The owner of the mark is prohibited by law from practicing a self-produced mark, because self-certification is inherently self-interested.

Certification marks account for a small percentage of intellectual property. Owners of certification marks are held to high standards of conduct: decisions about whether to certify a product or service must be based exclusively upon the criteria the owner has set for the mark. In other words, certification cannot be based on a user's willingness to pay a fee to the owner of the mark (other than a minimal fee covering administrative costs). In effect, the certifying entity must operate as a nonprofit.

Seen in this light, the Fair Employment mark is a simple and traditional idea innovatively applied in a new context. Commerce in the United States has nurtured a venerable tradition of labeling products to improve work conditions for groups of oppressed people. Trade union labels first came into circulation as a way of promoting shorter work days. In 1869, the Carpenter's Eight-Hour League of San Francisco created a stamp that permitted lumber mills to signal that they ran on an eight-hour schedule rather than a ten-hour schedule." This was typical of most union labels that followed, which were generally used to promote better working conditions and to guard against the use of tenement-house, sweatshop, and prison labor. ${ }^{12}$ By

8. 15 U.S.C. $\$ 1054$ (2000).

9. Id. $\S 1064$. Licensing a trademark while giving up control of the product would constitute abandonment of the mark under federal trademark law. Id.

10. See id.; id. §1054.

11. Ernest R. Spedden, The Trade-Union Label $10 \mathrm{n} .2$ (1910).

12. Bureau of Int'l Labor Affairs, U.S. Dep't of Labor, By the Sweat and Toll of Children: Consumer labels and Child Labor 7 (1997), http:/www.dol.gov/llab/media/ reports/iclp/sweat $4 /$ sweat 4 .pdf. 
the turn of the century, union labels were used by groups in many industries. ${ }^{13}$

Although some early labeling schemes attempted to promote the quality or healthfulness of the product, the union label stood primarily for "better pay and improved work conditions." ${ }^{14}$ For example, even before Congress enacted legislation outlawing child labor, private organizations devised and administered labeling programs to promote products manufactured without the use of child labor. ${ }^{13}$ Now U.S. consumers are faced with a growing number of products manufactured in countries where employment laws are lax or nonexistent. ${ }^{16}$ In response to consumer concerns, many products in the United States bear marks relating to issues of moral import: environmental impact, animal testing, fair trade, sweatshops, and child labor. The Fair Employment mark would similarly permit consumers who care about gay rights to spend their money in ways consistent with their values.

\section{A. Minimalist Certification}

Although certification marks enjoy a long tradition, two aspects of the Fair Employment mark are quite nontraditional. First, we have structured the licensing agreement to minimize what we must certify as mark owners. While traditional certification-mark owners go out into the world and monitor licensees to make sure they are complying with the requirements of the mark, we have structured the license agreement so that we can certify without inspecting the licensee's employment practices. We do not certify that the employer does not discriminate. Instead, we certify two crucial things:

- The employer has promised not to discriminate in employment on the basis of sexual orientation.

- The employer has granted all of its employees and applicants express third-party beneficiary status to remedy any breach of the nondiscrimination promise.

Because the licensing agreement expressly includes both of these elements, we can truthfully certify these matters merely by certifying that the licensee has signed the license. Any employer that signs the licensing agreement simultaneously gains a right to use the mark and meets the minimum requisites for certification. At the same time, the licensee's employees gain a private right of action to enforce their quasi-ENDA rights.

This minimalist certification structure has three advantages. First, it allows a mark owner to provide meaningful certification with virtually no expense. Even though we do not certify that the employer does not dis-

13. Id. at 6. These groups included printers, bakers, wood workers, harness makers, iron molders, broom makers, coopers, photographers, shoemakers, custom tailors, mattress makers, blacksmiths, brewers, egg inspectors, barbers, and coal distributors.

14. Id. at 29.

15. Id. at 7-9.

16. Id. 
criminate, we are able to certify that the employer holds itself open to private suits or other remedial actions for discrimination. To deny that this is meaningful would be to deny the value of private rights of action under Title VII and other civil rights laws. Second, this structure is transparent. It makes clear to employers that we, as mark owners, are not profiting from the mark. Because of this structure, employers can obtain a license to use the mark without paying us a licensing fee. Third, this licensing structure allows us to emulate more closely the ENDA private cause of action. Employers need not worry that the mark owners will engage in vexatious litigation, because we do not have a right to sue for violations of the nondiscrimination promise.

\section{B. Third-Party Beneficiaries}

The second and related innovation in the structure of the license concerns the use of third-party beneficiary rights. In return for the right to use the mark, an employer expressly grants third-party beneficiary status to the same parties who could sue to enforce ENDA if it were enacted. Paragraph 5 of the License reads as follows:

THIRD-PARTY BENEFICIARIES. Licensee and Licensor agree to designate as express third-party beneficiaries of this agreement all persons and entities that would be entitled to sue if ENDA were in effect (including governmental civil rights enforcement agencies). In particular, Licensee and Licensor designate as express third-party beneficiaries all persons who are or have been employed by the Licensee or applied for employment with the Licensee during the term of the license. The Licensee and Licensor intend that these third-party beneficiaries will have the right to sue the Licensee for any breach of this agreement and have a legal right to the same remedies (including damages and injunctive relief) to which they would be entitled if ENDA were in effect. ${ }^{17}$

Through this agreement, the mark owner altruistically grants potential private rights of action to third parties.

While contract promises (including intellectual property licensing agreements) traditionally require a return element of consideration in order to be enforceable, it is well settled that express third-party beneficiaries can acquire enforceable contractual rights without providing consideration themselves. ${ }^{18}$ So long as the consideration is provided by another party to the contract-in this case, by the mark owner in granting the licensee the

17. See app. para. 5.

18. 13 Richard A. LoRD, Williston ON CONTRACTS $\$ 37: 26$ (4th ed. 2000) ("The rule regarding such situations has long been established: "where one makes a promise to another for the benefit of a third person, such third person may avail himself of the promise and bring an action thereon, although the consideration does not move directly from him.'" (quoting Hale v. Ripp, 49 N.W. 218, 219 (Neb. 1891))); see also Franklin Fire Ins. Co. v. Howard, 162 So. 683, 684 (Ala. 1935) ("II]f one person makes a promise for the benefit of a third party, such beneficiary may maintain an action thereon, though the consideration does not move from the latter."). 
right to use the mark - the beneficiaries' right to nondiscrimination is enforceable. ${ }^{19}$

In some cases, a genuine issue can arise about whether the plaintiff is a legitimate and intended third-party beneficiary of the contract. Courts and commentators have debated whether third parties can sue when they are merely unnamed, implicit third-party beneficiaries. But when the signatories to a contract expressly intend to authorize suit by a well-defined, clearly identified group, then a right of action is much more certain. ${ }^{20}$ The precise identities of individuals within a benefited group need not be known at the time of the contracting, as long as the agreement makes clear the characteristics of the group as a whole. ${ }^{21}$ In the case of the mark, the licensing agreement explicitly makes job applicants and employees of the licensee the intended third-party beneficiaries of the contract. This is a finite, clearly defined population, subject to easy verification.

The licensing agreement thus is an example of using third-party beneficiary status to link a private contract to a public or social good. While this strategy is rarely deployed, there is no legal impediment to using consumer contracts, or other agreements, to combine private and public goals. The Fair Employment licensing agreement grants the right to use the mark, but only if the licensee agrees to create rights of action in third parties: the licensee's job applicants and employees.

\section{The Benefits of Privatizing ENDA}

Together, the license structure of minimal certification and third-party altruism allows the Fair Employment mark to effect a privatization of ENDA. Instead of the mandatory nondiscrimination duties of ENDA, the mark creates an opt-in mechanism for employers that want to contract affirmatively for ENDA duties. Richard Epstein has railed against the mandatory nature of Title VII and other civil rights duties, ${ }^{22}$ but even healong with all thorough-going libertarians-ought to embrace the FE mark as expanding freedom of contract.

The mark also represents a new form of federalism. We traditionally think of federalism as competition among jurisdictions, with individual

19. Fourth Ocean Putnam Corp. v. Interstate Wrecking Co., 487 N.Y.S.2d 591, 594-95 (App. Div. 1985) ("It is true that where performance is to be made directly to a third party, there is at least 'a presumption that the contract was for the benefit of the third party.' However, 'the intention of the promisee is of primary importance, since the promisee procured the promise by furnishing the consideration therefor." " (citations omitted)).

20. 13 LoRD, supra note $18, \S 37: 8$ ("“A]s a general rule, a third party may enforce a promise as having been made for his benefit, if it appears from the promise or in the light of the surrounding circumstances that he was intended in fact to be a donee beneficiary of the promisee.").

21. Pappas v. Jack O.A. Nelsen Agency, Inc., 260 N.W.2d 721, 725-26 (Wis. 1978) ("Thus, the precise identity of the third-party beneficiary need not be ascertainable at the time of the agreement so long as the agreement specifies or identifies a group or class to whom the party must belong to benefit thereby.").

22. Richard Epstein, Forbidden Grounds: The Case Against Employment DiscrimiNATION LAWS (1992). 
states acting as the laboratories for legal experimentation. The Fair Employment mark is an example of "corporate federalism," in which individual business organizations are allowed to experiment with different regulatory structures. Of course, any regime with freedom of contract allows corporate experimentation. But the Fair Employment mark allows a type of structured experimentation. It is thus akin to corporate statutes that give individual businesses discrete choices, e.g., opting into particular "control transaction" protections or opting out of certain duties of care.

\section{Amelioration}

If a substantial number of employers signed the license, ${ }^{24}$ the mark would provide three different types of incremental benefits: amelioration, demonstration, and realignment. ${ }^{25}$ First, the mark would ameliorate the problem of orientation discrimination for covered workers. Outside of the states that expressly provide private causes of action, employees sometimes have no legal remedy for claims of sexual orientation discrimination in employment. Even employers that include sexual orientation in their nondiscrimination policy are sometimes found not to have made a binding promise not to discriminate. ${ }^{26}$ The extension of private causes of action to unprotected workers is not just a symbolic act. It would remedy real harms. As in the early years of Title VII, there are many examples of blatant disparate treatment in conditions of employment. Even in businesses that voluntarily adopt the mark and that genuinely oppose discrimination, gay and lesbian workers may be subject to blatant disparate treatment from managers or coworkers. ${ }^{27}$ The mark provides a means to address these wrongs.

23. See, e.g., Del. CODE ANN. tit. 8, § 203 (2001) (opt-out law); GA. CoDE ANN. §§ 14-21110 to $-1113,-1131$ to -1133 (2003) (opt-in-via bylaw amendment-business combination and fair price laws). For a complete list of anti-takeover law statutes (most opt-out, a few mandatory, and only Georgia with opt-in), see Patrick S. McGurn \& Mary Frances Spatola, State Takeover LAws (2d ed. 1995). For director liability statutes, see DeL. CoDE ANN. tit. 8, § 102(b)(7) (2001) (opt-in regime), and Ohio Rev. Code ANN. $\$ 1701.59$ (D) (LexisNexis 2004) (opt-out statute).

24. Part III will predict which employers are most likely to sign the agreement.

25. We have argued that our "inclusive command" proposal represents another incremental strategy for providing these three types of benefits with regard to employment discrimination in the military. See Ian Ayres \& Jennifer Gerarda Brown, Straightforward: How to Mobilize Heterosexual Support for Gay Rights 116-44 (2005); Jennifer Gerarda Brown \& Ian Ayres, The Inclusive Command: Voluntary Integration of Sexual Minorities into the U.S. Military, 103 Mich. L. REv. 150 (2004).

26. This enforceability of nondiscrimination policies is discussed infra Part III.A.

27. See, e.g., Empire State Pride Agenda, Anti-Gay/Lesbian Discrimination in New YoRK STATE 1 (2001), http://www.prideagenda.org/pride/survey.pdf ("In New York, anti-gay job discrimination in employment is pervasive, with more than one-third of the respondents $(36 \%)$ experiencing some form of job-related discrimination within the last five years. . . 8 $\%$ were fired because of their sexual orientation. ... 27\% were verbally harassed at the workplace (e.g., being called names such as 'faggot,' 'dyke,' 'bulldagger,' 'sissy,' 'queer,' or other anti-gay words). . . 7\% were physically harassed at the workplace because of their sexual orientation (e.g., being chased, followed, or threatened with physical violence).... $10 \%$ were given a negative performance 


\section{Demonstration}

Second, if the mark succeeds, it will produce a demonstration effect that could inform Congress and state legislators about the advisability of passing ENDA or state laws prohibiting discrimination. If 500,000 employees were covered by the mark, legislators would learn something over time about expected litigation rates and the magnitude of potential liability. Granted, this litigation information would provide only a lower bound on potential claims since employers that volunteer for potential liability are less likely to have discriminatory practices than those that do not. But even this lower bound information is useful in demonstrating that ENDA would not open a floodgate of litigation. If in fact the litigation rates and awards are reasonably low under the mark, ${ }^{28}$ it would demonstrate that the form of potential liability proposed under the statute could be managed-by employees and covered employers alike.

The inevitable litigation that would arise under the mark would also provide legislators with information about how courts might interpret ENDA if it were enacted. The Fair Employment mark allows courts for the first time to create persuasive precedent about the meaning of statutory language before the statute is passed..$^{29}$ At first, this seems impossible-statutes must be enacted before they can be interpreted. And if it were possible, why would this be the first time it ever happened? The simple answer is that to our knowledge the licensing agreement is the first private contract that explicitly adopts the words of a proposed statute in order to put its provisions into effect. ${ }^{30}$ As shown in the Appendix, the licensing agreement expressly states its goal: "WHEREAS Licensee desires to privately commit to nondiscrimination as defined in the Employment Non-Discrimination Act (ENDA) as proposed in S. $1705,108^{\text {th }}$ Cong., $1^{\text {st }}$ Sess. (2003)., ${ }^{31}$ This ver-

evaluation because of their sexual orientation."); see also Dave Munday, Gay Workers Fear for Their Jobs; Nondiscrimination Policies Still Scarce, Post \& CoURIER, Apr. 4, 2004, at E1.

28. Evidence from the states that have already provided for private rights of action shows that the rates of litigation are very low. U.S. Gen. Accounting OfFICE, PUBL'N No. GAO/OGC-987R, Sexual-Orientation-Based Employment Discrimination: States' Experience with Statutory Prohibitions (1997) (explaining that in states with statutes making it illegal to discriminate in employment on the basis of sexual orientation, relatively few formal complaints or lawsuits alleging such discrimination had been filed); U.S. Gen. Accounting OfFice, Publ'N No. GAO/OGC-00-27R, Sexual-Orientation-Based Employment Discrimination: States' ExPERIENCE with Statutory Prohibitions Since 1997 (2000) (arguing that both the number of complaints of sexual orientation discrimination in employment and the percentage of such complaints as a portion of overall complaints of employment discrimination filed "may still be characterized as relatively small;" the number of lawsuits pursuant to these state laws was even smaller).

29. Of course, the precedent will not be persuasive in all cases because some canons of contract interpretation are inconsistent with canons of statutory interpretation. For instance, although policy goals will often inform statutory interpretation, public policy implications will usually take a distant second to party intent when courts construe a contract. And statutes are not generally construed against the drafting party.

30. Much more common is the reference to statutes or other public law in contracts specifically designed by parties to opt out of the default.

31. App. pmbl. 
sion of the ENDA bill is attached to the license; the substantive "Standards of Fair Employment" included in the license are taken word-for-word from the bill. Thus, when a court is asked to interpret the meaning of the words in the license, it will be interpreting the same words that appear in the proposed bill. Even though the court will be interpreting a contractual promise, the foregoing "whereas" clause will lead the court to ask whether the employer's conduct would have run afoul of ENDA had the bill been enacted.

Information about how courts will interpret ENDA can help quell legislative concerns about supporting the bill. Even though the next Section will show that the bill is a narrow prohibition of disparate treatment alone, legislators may still worry that "activist judges" will extend the statute beyond its borders. Even though the statute does not reach discrimination on the basis of gender identity and expression, legislators may be concerned that ENDA will restrict employers' ability to regulate employee appearance and conduct. Resolving these possible ambiguities can ease the bill's passage-in part because the legislators can expressly approve or disapprove of such precedent. Just as Congress expressly disapproved of some Supreme Court precedent and expressly approved of other precedent when it passed the Civil Rights Act of 1991, so too Congress would have the option of explicitly embracing or rejecting particular court interpretations of the Fair Employment mark licensing agreement when considering whether to pass ENDA. The substantive language of the nondiscrimination requirement in a future proposal of ENDA might even change in response to this precedent.

There are important differences between pre-passage license precedent and post-passage ENDA precedent. As a formal matter, an interpretation of contractual language would not be binding on a court interpreting statutory language in a post-passage case. This is particularly true when different courts are involved. With the exception of a few federal cases brought under diversity jurisdiction, the bulk of the license precedent would come from state courts, while post-passage ENDA interpretations would result from federal litigation. Federal courts might be reluctant to defer to state court interpretations of federal statutory language-especially when those interpretations had occurred before the federal statute had been passed. Then again, affirmative references to these state court decisions in the congressional record when the statute is subsequently enacted could radically raise the precedential value of the state court decisions.

The flip side is that congressional action could also render this prepassage license precedent irrelevant. The language of many bills is significantly amended before passage. The language of proposed legislation often changes from year to year as revised bills are introduced in successive legislative sessions. Our licensing agreement takes account of this possibility by allowing us to update the licensing language on an ongoing basis, keeping pace with the legislative state of play. ${ }^{32}$

32. Although we, as owners of the mark, may not unilaterally modify the license, we intend to propose modifications to conform the license to updated versions of the bill that are formally 


\section{Realignment}

Finally, the coverage of a substantial number of employees creates new legislative opportunities that might serve as a wedge issue to realign politicians who currently oppose ENDA. At first, it might seem that ENDA already represents an irreducible legislative minimum. It is carefully crafted solely to prohibit disparate treatment. It does not allow disparate-impact claims or claims for health benefits by unmarried domestic partners. It expressly does not require affirmative action. It would seem that there is not much left on which gay rights proponents could compromise. ${ }^{33}$

The Fair Employment mark, however, illuminates new opportunities for compromise. These areas of compromise emerge when we consider the inherent limits on freedom of contract illustrated by the mark. There are some things parties to a contract cannot effect, and these gaps give Congress a chance to act. The most important respect in which the licensing agreement cannot replicate ENDA is the enforcement regime. Under ENDA, the Justice Department and the Equal Employment Opportunity Commission (EEOC) — as well as individual employees and applicants-would be empowered to sue employers that discriminate. The licensing agreement goes as far as it can in naming as third-party beneficiaries this same set of plaintiffs: to wit, "all persons and entities that would be entitled to sue if ENDA were in effect." ${ }^{34}$ This is an attempt to grant government actors enforcement power. Yet while this provision is sufficient consent on the part of the corporate licensee for such enforcement, the government actors need separate legislative authorization to be able to bring an ENDA-like enforcement action. Put simply, private parties by themselves cannot give the Justice Department or the EEOC power to sue-they need congressional action for that.

However, each licensing agreement could be seen as an invitation to congressional action. If a million employees were covered by the license, gay rights advocates might lobby Congress to empower the civil rights agencies to enforce the nondiscrimination policy against those corporations that had volunteered. Such an "opt-in" enforcement statute might garner the support of legislators who have been reluctant to impose ENDA's requirements on unwilling companies.

Indeed, it is a short step to see the license agreement not only as a vehicle for "opt-in" enforcement, but also as a call for an "opt-in" version of ENDA itself. Congress might easily displace the need for the mark's contractual commitment by passing a statute that makes ENDA duties binding only on companies that affirmatively opt for the statute-possibly by for-

introduced into Congress. New licensees will opt into the latest version of the ENDA bill (or comparable legislation).

33. In fact, ENDA could be pared back on a number of other grounds. For example, class actions could be prohibited or damages could be more severely capped.

34. App. para. 5 . 
mally registering with the EEOC.$^{35}$ Free-market conservatives simply have no argument to resist such legislation. Richard Epstein, for example, attacked the mandatory nature of Title VII in his 1992 book, Forbidden Grounds. ${ }^{36}$ For Epstein, the chief evil of Title VII is that it restricts freedom of contract. But Epstein should have no problem with a statute that permits firms to decide whether they want to be covered by civil rights laws.

Indeed, Epstein's criticism of the mandatory nature of Title VII only suggests that lawmakers should permit firms to contract around the default set of rights regarding employment discrimination. This kind of criticism tells us nothing about what the appropriate default rule should be. ${ }^{37}$ Epstein's argument in Forbidden Grounds is a contractual non sequitur. If Epstein believes that the mandatory nature of a civil rights law is unwarranted, he can certainly suggest that legislators make the statutory duty waivable. Epstein needs a separate kind of argument-which he never provides-to show that an opt-in statute is superior to an opt-out statute. ${ }^{38}$ Epstein argues for the repeal of Title VII (implicitly turning it into an opt-in statute, creating no employment rights unless employers affirmatively contract for them), but he does not consider whether an opt-out default would be superior.

The same opt-in/opt-out debate lies at the end of this ENDA thought experiment. Once Congress begins to consider the opt-in version of ENDA described above, it is natural to ask whether an opt-out version of ENDA might be even better. Both are formally equivalent from a libertarian freedom-of-contract perspective because both give employers the identical legal option to embrace or avoid nondiscrimination duties. But default choice matters. Default inertia is the iron law of contracting. ${ }^{39}$ We would undoubtedly see more employees covered by nondiscrimination promises in the shadow of an opt-out statute than an opt-in statute. ${ }^{40}$ While the Fair Employment mark comes close to replicating the effects of an opt-in statute, only lawmakers can create an opt-out statute.

Stepping back, we can now see a variety of opportunities for incremental legislative progress. While the minimalistic ENDA duties initially

35. Such a statute would have to govern the conditions under which a firm might subsequently "opt out" of coverage. In the spirit of incrementalism, we believe that this should be allowed as long as there was sufficient public notice.

36. EPSTEIN, supra note 22.

37. See generally Ian Ayres \& Robert Gertner, Filling Gaps in Incomplete Contracts: An Economic Theory of Default Rules, 99 YALE L.J. 87 (1989) [hereinafter Ayres \& Gertner, Filling Gaps in Incomplete Contracts]; Ian Ayres \& Robert Gertner, Majoritarian vs. Minoritarian Defaults, 51 StaN. L. Rev. 1591 (1999) [hereinafter Ayres \& Gertner, Majoritarian vs. Minoritarian Defaults].

38. Ian Ayres, Empire or Residue: Competing Visions of the Contractual Canon, in LEGAL CAnons 47, 58 (J.M. Balkin \& Sanford Levinson eds., 2000).

39. Put formally, in equilibrium when rule $X$ is the default, one would expect to see a higher proportion of contractors covered by rule X than by any other term. See Ayres \& Gertner, Majoritarian vs. Minoritarian Defaults, supra note 37, at 1598.

40. Ayres, supra note 38, at 58 . 
did not appear amenable to statutory compromise, we have identified three incremental way stations that become visible as a consequence of the Fair Employment mark. First, Congress might empower the federal civil rights agencies to enforce the mark's duties against voluntary licensees. Second, Congress might displace the mark by creating an opt-in ENDA statute. And most expansively, Congress might create an opt-out ENDA statute allowing employers to avoid potential liability by publicly disclaiming the statute's nondiscrimination duties. While the Fair Employment mark goes a long way toward replicating the rights and responsibilities of the proposed statute, these final two default statutes would solve both the precedential and enforcement deficits of the mark. Precedents created under either an opt-in or opt-out statute would be solid federal precedent in the event of later mandatory passage of the statute. And these contractible statutes would create the public enforcement add-on that is currently missing from the licensing agreement.

\section{Tailoring the Coverage of the Licensing AgreEMENT}

This Part defends in more detail what is included in and excluded from our licensing agreement. As for inclusion, we have simply tried to impose as nearly as possible the legal duties of ENDA, a bill that has been proposed repeatedly since 1993 but has not yet been enacted by Congress. ${ }^{41}$ The central goal of the bill was to grant employees and applicants a private right of action if they are subject to disparate treatment because of their sexual orientation. In effect, ENDA would include sexual orientation in the group of characteristics that Title VII already makes off-limits as the basis for the terms and conditions of employment. ${ }^{42}$ Paragraph 4 of the licensing agreement sets out these substantive duties:

STANDARDS OF FAIR EMPLOYMENT. Licensee promises not to engage in the following employment practices:

(1) "to fail or refuse to hire or to discharge any individual, or otherwise to discriminate against any individual with respect to the compensation, terms, conditions, or privileges of employment of the individual, because of such individual's sexual orientation;" ENDA, S. 1705, § 4 (a)(1) (attached hereto) or

(2) "to limit, segregate, or classify the employees or applicants for employment of the employer in any way that would deprive or tend to deprive any individual of employment or otherwise adversely affect the

41. See J. Banning Jasiunas, Note, Is ENDA the Answer? Can a "Separate but Equal" Federal Statute Adequately Protect Gays and Lesbians from Employment Discrimination?, 61 OHIO Sr. L.J. $1529(2000)$. In using the language of ENDA, we are placing the words of Chai Feldblum, one of its principal drafters, into our licensing agreement. See generally Georgetown University, Chai R. Feldblum, http://www.law.georgetown.edu/curriculum/tab_faculty.cfm?Status=Faculty\&Detail=251 (last visited Apr. 20, 2005).

42. Representative Barney Frank, a supporter of ENDA, has stated that ENDA would result in legal protection "for gay and lesbian people" identical to the protections granted by Title VII. Jasiunas, supra note 41 , at $1545-46$. 
status of the individual as an employee, because of such individual's sexual orientation;" ENDA, S. 1705, § 4 (a)(2) (attached hereto)

(3) to discriminate against any individual because of the sexual orientation of the individual "in admission to, or employment in, any program established to provide apprenticeship or other training;" ENDA, S. 1705, $\S 4$ (d) (attached hereto)

(4) to discriminate against an individual because such individual opposed any of the employment practices described in subsections (1) through (3), "or because such individual made a charge, testified, assisted, or participated in any manner in an investigation, proceeding, or hearing" concerned with this License. ENDA, S. 1705, § 5 (attached hereto)

The employment practices described in any of subsections (1) through (3) "shall be considered to include an action described in that subsection, taken against an individual based on the sexual orientation of a person with whom the individual associates or has associated." ENDA, S. 1705, § 4 (e) (attached hereto). ${ }^{43}$

But unlike Title VII, our license follows ENDA in expressly limiting its coverage to claims of disparate treatment. Like ENDA, the licensing agreement expressly disclaims disparate-impact and affirmative-action duties and does not require employers to provide employee benefits to domestic partners. $^{44}$

In tailoring the coverage of the license, we cleave to the ENDA duties for several reasons. First, they are clear and simple. The idea of having a legally enforceable private right of action to be free from disparate treatment in employment on the basis of an impermissible characteristic resonates with a core conception of civil rights. By excluding disparate impact coverage, we make it harder to characterize the license as "a quota bill." By eschewing any duty of affirmative action, we hope to silence those who would complain about "special rights."

Moreover, the ENDA duties have become a focal point of debate, drafting, and lobbying. The substantive language of our license has been repeatedly introduced into Congress. Over a hundred corporations have said that they want the bill to be passed. ${ }^{45}$ Potential licensees do not need to flyspeck whether they agree with our particular drafting choices. Just as we disclaim enforcement power to assure potential licensees that we will not be vexatious litigators, so we disclaim drafting power in choosing the contours

43. App. para, 4.

44. See id. paras. 6 and 7.

45. For the full list of companies, see Human Rights Campaign Foundation, Corporations and Small Businesses Endorsing the Employment Non-Discrimination Act (ENDA), http://www.hrc.org/Template.cfm?Section=Endorsing_ENDA\&CONTENTID=17977\&TEMPLATE $=/$ ContentManagement/ContentDisplay.cfm (last visited Apr. 20, 2005). 
of licensee duties to assure them that we have not inserted an unduly burdensome or unreasonable requirement. ${ }^{46}$

In keeping with this principle, we have not attempted to reengineer or improve upon the ENDA duties. Since ENDA would allow class actions, our license would allow class actions. ${ }^{47}$ Since ENDA would allow suits for coworker harassment, our license would allow suits for coworker harassment. ${ }^{48}$

But our license would also allow the same employer countermoves to limit potential liability. Since ENDA would allow arbitration agreements, our license would as well. Under ENDA (as with Title VII), discrimination disputes would be arbitrable so long as the arbitration agreement was conscionable. ${ }^{49}$ We believe the same standards should generally apply to the licensing agreement, ENDA, and Title VII. ${ }^{50}$ The ability to channel employment disputes into arbitration has been important to many employers. Arbitration can also be a valuable way to manage risk and curtail potential liability, particularly for employers that are repeat players. ${ }^{51}$ Since ENDA

46. The license is thus an example of what Ian Ayres and Barry Nalebuff have called the KISS principal-"Keep It Similar, Stupid." The idea is that securing support for an innovation is often easier when the implementation will be similar to that of a familiar plan; in this way, the potential adopter is not overwhelmed with change and can focus on the crucial innovative element. See Ian Ayres \& Barry Nalebuff, Why Not? How to Use Everyday Ingenuity to Solve ProbLEMS BIG AND SMALL, 203-08 (2003).

47. Section 12(b) of ENDA states that "[t]he procedures and remedies applicable to a claim alleged by an individual for a violation of this Act are ... the procedures and remedies applicable for a violation of [T]itle VII of the Civil Rights Act of 1964 (42 U.S.C. 2000e et seq.)." H.R. 3285, 108th Cong. §12(b) (2003). Courts have long held that class actions are available and, indeed, often necessary in Title VII cases. See, e.g., Griggs v. Duke Power Co., 401 U.S. 424, 426 (197I) ("Congress provided, in Title VII of the Civil Rights Act of 1964, for class actions for enforcement of provisions of the Act."); Culpepper v. Reynolds Metals Co., 421 F.2d 888, 891 (5th Cir. 1970) (deciding that the court would construe Title VII to allow for class actions "to make sure that the Act works"); Jenkins v. United Gas Corp., 400 F.2d 28, 34 (5th Cir. 1968) ("II]f class-wide relief were not afforded ... the result would be the incongruous one of the Court ... itself being the instrument of racial discrimination .... .); Hall v. Werthan Bag Corp., 25l F. Supp. 184, 186 (M.D. Tenn. 1966) ("Racial discrimination is by definition a class discrimination.").

48. An employer may be liable for coworker harassment under Title VII if the employer's negligence creates a "hostile work environment." Ocheltree v. Scollon Productions, Inc., 335 F.3d 325, 330-32, 334 (4th Cir. 2003) ("An employer cannot avoid Title VII liability for coworker harassment by adopting a 'see no evil, hear no evil' strategy.").

49. See Circuit City Stores, Inc. v. Adams, 532 U.S. 105 (2001) (holding that a contract requiring arbitration of all employment disputes is enforceable under federal law), remanded to 279 F.3d 889 ( 9 th Cir. 2001) (holding that ordinary principles of state contract law determine validity of agreement to arbitrate and, because arbitration agreement was both procedurally and substantively unconscionable under California law, it was unenforceable), cert. denied, 535 U.S. 1112 (2002).

50. Arguably, since the licensing agreement does not include an arbitration clause, job applicants would be free to litigate claims arising from it. Even employees who signed employment contracts containing arbitration clauses might be able to litigate violations of the employment mark, qua third-party beneficiaries of the licensing agreement. The scope of the arbitration clause within the employment contract could be broad enough, however, to include the licensing agreement, since a violation of the licensing agreement would certainly "arise out of or relate to" the contract of employment.

51. Lisa B. Bingham, Employment Arbitration: The Repeat Player Effect, 1 Emp. RTs. \& EMP. PoL'Y J. 189, 209 (1997) (arguing that employees lose more often, and arbitrators award damages to employees less frequently and in lower amounts, when the employer is a repeat player); Lisa B. Bingham, On Repeat Players, Adhesive Contracts, and the Use of Statistics in Judicial Review of 
would allow waiver of class action rights, so would our license. ${ }^{52}$ And finally, since ENDA would require filing of claims within 180 days of the occurrence of a violation, so would our license. ${ }^{53}$

Our meta-goal is to come as close as possible to ENDA rights and responsibilities without ever going beyond them (that is, without ever imposing more duties on employers than would be imposed by the statute). We have already discussed a couple of dimensions in which our license falls short of ENDA: it does not grant civil rights agencies an independent ability to enforce, and it cannot create federal court jurisdiction to hear claims arising under our license. ${ }^{54}$ Our license may also fall short of ENDA with regard to certain remedies. Private parties may not contract for punitive damages. ${ }^{55}$ Thus, even if punitive damages would be available to plaintiffs under ENDA, courts may be unwilling to grant them to plaintiffs for breach of the licensing agreement. Similar logic may restrict courts' willingness to grant certain types of injunctive relief. Specific enforcement of promises is at times restricted by a variety of doctrines (such as the irreparable-harm rule) that are not at play in remedying statutory civil rights claims. ${ }^{56}$ These

Employment Arbitration Awards, 29 McGeorge L. Rev. 223, 234 (1998) (noting that in repeat player cases, employees recover only eleven percent of what they demand, but in cases against employers that are not repeat players, they recover about forty-eight percent of what they demand).

52. Many arbitration agreements do not provide for class actions. As long as the arbitration agreement is not found to be unconscionable, waivers of class action rights will be upheld. See, e.g., Gilmer v. Interstate/Johnson Lane Corp., 500 U.S. 20, 32 (1991) (upholding waiver of class action rights in arbitration of claims arising under the Age Discrimination in Employment Act); Livingston v. Assocs. Fin., Inc., 339 F.3d 553 (7th Cir. 2003) (enforcing an arbitration agreement prohibiting class actions of claims arising under Truth in Lending Act); Randolph v. Green Tree Fin. Corp., 244 F.3d 814, 817-18 (11 th Cir. 2001) (same); Johnson v. W. Suburban Bank, 225 F.3d 366, 377-78 (3d Cir. 2000) (same), cert. denied, 531 U.S. 1145 (2001). But see Ingle v. Circuit City Stores, Inc, 328 F.3d 1165, 1172-73 (9th Cir. 2003) (striking down arbitration agreement for unconscionability in part due to its prohibition of class actions).

53. See app. para. 14 ("Any lawsuit by a third-party beneficiary for violation of the Standards of Fair Employment shall be filed within one hundred and eighty days after the alleged violating employment practice occurred."). Section 12(b) of ENDA ordains that "[t]he procedures and remedies applicable to a claim alleged by an individual for a violation of this Act are ... the procedures and remedies applicable for a violation of [T] itle VII of the Civil Rights Act of 1964 (42 U.S.C. 2000 e et seq.)." See H.R. 3285, 108th Cong. \$12(b) (2003). And 42 U.S.C. \$2000e-5(e)(1) states that charges of unlawful discrimination must be filed with the EEOC within 180 days of the occurrence. There is one dimension in which our license arguably goes beyond ENDA. ENDA would require private plaintiffs to file a charge with the EEOC and obtain a "right to sue" letter before suing in federal court. (A similar duty to file with the state human rights commission is in place in California under its state nondiscrimination statute). Plaintiffs under our license would not need to exhaust this administrative remedy before filing suit. Although this might impose fewer procedural burdens on license-based plaintiffs, it is important to remember that exhaustion of administrative remedies does not substantively burden plaintiffs because plaintiffs in any case retain a right to sue. Therefore the substantive effects of ENDA/Title VII and the license agreement should be the same.

54. But as discussed supra Section 1.C.3, Congress could empower these agencies to enforce the license against licensees and to allow enforcement by private or public plaintiffs in federal court.

55. Punitive damages can arise out of bad faith conduct or promissory fraud. See generally Ian ayres \& Gregory Klass, Insincere Promises: The LaW of Misrepresented Intent (2005).

56. See Douglas Laycock, The Death of the Irreparable Injury Rule, 103 HARv. L. REv. 687 (1990). The trend seems to be toward enforcement of specific performance clauses. See U.C.C. § $2-$ 
shortfalls from ENDA point out the limits of contracting. But at the end of the day, the license comes reasonably close to recreating the statutory duties, and the license's deviations from ENDA (especially the restriction on punitive damages) should assuage employer fears about signing on to unlimited liability.

We have also intentionally granted licensees the power to change their minds. While the term of the license is five years (and by default automatically renews), we allow licensees to terminate the agreement at any time and for any reason. In contrast, we as licensors can terminate the agreement prior to the term of the agreement only for cause-that is, if the licensee violates the standard for Fair Employment. This asymmetry in termination rights is intended to assure licensees in yet another way that they have substantial control over their fate if their perceived liability or other risk exceeds their expectations.

Although the minimalism and focal nature of our license duties have considerable appeal, some readers might protest that we have set the bar too low. While ENDA clearly represents a major advance in employment protections for gay men and lesbians, the bill's proponents in Congress have had to limit its reach in order to make it more politically palatable. The statute has an understandably modest goal. But as applied to the license, is this goal too modest? Considering that the license is a voluntary choice of employers (who in part are seeking a marketing advantage), should the license duties be expanded to secure more than a simple promise not to discriminate?

In the remainder of this Part, we explore five potential expansions in coverage. The first four concern substantive licensor duties related to gender identity and expression, healthcare coverage for employees' same-sex domestic partners, the Human Rights Campaign Corporate Equality Index, ${ }^{57}$ and affiliate corporations (concerning alternative enforcement options). As important and helpful as all of these potential expansions might be, in the end, we believe it is useful to retain a license that mirrors the language of ENDA as formally proposed in Congress. The good news is that in this world of corporate voluntarism, we need not make either/or decisions. The Fair Employment mark is entirely consistent with these more ambitious approaches to LGBT employment protection. Corporations are contractually free to embrace both our ENDA-based Fair Employment mark as well as additional obligations to their employees.

$716 \mathrm{cmt} .1$ (1999) ("[T]his Article seeks to further a more liberal attitude than some courts have shown in connection with the specific performance of contracts of sale.").

57. The Human Rights Campaign (HRC) is America's largest gay, lesbian, bisexual, and transgender civil-rights organization. HRC lobbies Congress, mobilizes grassroots action in diverse communities, invests strategically in congressional campaigns, and increases public understanding through education and communication. See Human Rights Campaign Foundation, About the Human Rights Campaign: Our Mission Statement, http://www.hrc.org/Template.cfm?Section=About_HRC (last visited Jan. 25, 2006). 


\section{A. Gender Identity and Expression}

Probably the most troubling drafting choice we made concerns gender identity. By excluding gender identity and gender expression from protected status, our licensing agreement follows the contours of every version of ENDA that has been introduced in Congress to date. This means that transgender employees would not be covered. ${ }^{58}$ In the view of ENDA's chief congressional sponsors, including gender identity or expression in the bill would effectively make it impossible to enact. ${ }^{59}$

Gender identity illustrates well the difficult choices that an incremental approach requires. Is it ever appropriate to secure gains for only some? Is it moral to jettison the $T$ in the LGBT community? Our license, like ENDA, sacrifices the interests of transgendered people-leaving them out of the calculus-in its attempt to secure a basic civil right for gay, lesbian, and bisexual employees. ${ }^{60}$ The idea of incrementalism works on the assumption (or, at least, the hope) that fair treatment on the basis of sexual orientation is a step in the right direction, a step that brings us closer to fair treatment on the basis of gender identity at some point in the not-too-distant future. Such pragmatic choices, though difficult, are not unique to this issue. Civil rights advocates have constantly struggled with the question of when and whether to push for "half a loaf."

58. Transgender is a broad term to cover a variety of gender identities; the term can refer to cross-dressers, pre- and post-op transsexuals, inter-sexed people (those born with ambiguous genitalia, or both male and female sex characteristics), and bi-gendered people (who feel comfortable in both male and female identities). When gender identity or expression is omitted from employment protection, employers can use behavior or characteristics that are gender nonconforming as the basis for disparate treatment.

59. Adrian Brune, HRC Vows No ENDA if No Trans Protection: Dramatic Policy Shift Follows Protests, Lobbying Effort, WASH. BLADE, Aug. 13, 2004, available at http:// www.washingtonblade.com/2004/8-13/news/national/enda.cfm (quoting Winnie Stachelberg, Human Rights Campaign's political director, as saying in 2003, "Now is not the time to add gender identity to ENDA. I listen to members of Congress and many of them-not all of them, but manyhave said adding [transgender protections] will slow passage of this bill down."); Roslyn Manley, New "Unified" Bill to Replace ENDA, http://www.tgcrossroads.org/news/archive.asp?aid=740 (last visited Jan. 8, 2006) (quoting Barney Frank as saying, "Maybe [adding protections for gender identity or expression] won't cause any loss of support. Maybe it's an easy inclusion. This is what we have to check and see.... Connecticut Republican Christopher Shays, one of ENDA's lead sponsors, has already signaled that he will drop off the bill if gender rights language is added.").

60. We should note, however, that even putting aside the interests of transgender employees, some have argued that gay, lesbian, and bisexual employees need gender identity and expression in ENDA to gain full protection. To the extent that gay, lesbian, and bisexual employees exhibit characteristics or behavior that do not conform to gender stereotypes or expectations, employers would be able legally to subject them to disparate treatment on a basis separate from sexual orientation. Because sexual orientation and other aspects of gender can be difficult to disentangle, some argue, gender identity and expression protection is necessary in order to give gay, lesbian, and bisexual employees full protection. See Cheryl Jacques, Putting the ' $T$ ' into ENDA: HRC's Board Has Decided Not to Support ENDA Without Transgender Protections, Wash. BLADE, Aug. 13, 2004, available at http:/www.washingtonblade.com/2004/8-13/view/columns/putting.cfm.

61. In Connecticut in 2005, for example, marriage equality advocates had to make tough choices about whether to support a bill that granted civil-union but not full-marriage rights to samesex couples. If, as German-Prussian politician Otto Von Bismarck once remarked, "politics is the art of the possible," such compromises can be justified as ways of doing what is "possible" as soon as 
In the past, the Human Rights Campaign (HRC) has been the primary gay-rights lobbying group supporting ENDA as proposed, despite HRC's general position that gender identity also deserves protection. But HRC has more recently moved toward inclusion. In the summer of 2004, HRC announced that it would not support any version of ENDA that excluded gender identity. ${ }^{62}$

While reasonable people of good faith can differ on this difficult issue, we cleave to the existing exclusion of gender identity in ENDA solely for pragmatic reasons. Barney Frank says that he has always wanted transgender protection in ENDA; nonetheless, he says,

Civil rights bills have never passed as all or nothing .... You go in steps.

The first civil rights bills didn't include voting or housing, but that didn't stop us from trying to get them passed. Every time you pass a partial civilrights bill you reduce the fears you will run into for the next version. ${ }^{63}$

Gender identity has been excluded from every version of ENDA introduced in Congress because sponsors believe that including gender identity would doom such a bill to defeat. For many employers, inclusion of gender identity in the company's written nondiscrimination policy would be seen as too radical a move to be attempted, and they would opt out of using the mark despite their willingness to include sexual orientation in the policy. Just as the anxiety of the shower has driven military discrimination, ${ }^{64}$ it is our sense that a certain anxiety of the restroom (as in, "which bathroom will he/she use?") has fueled the reaction to coverage of gender identity. Only 58 of the 379 companies rated in HRC's Corporate Equality Index survey made reference to gender identity characteristics or expression in their primary nondiscrimination statements. ${ }^{65}$ However, things may continue to change and change quickly. Our intention is to conform the license to the potentially evolving language of ENDA as reflected in legislation embraced by major congressional cosponsors. As long as Barney Frank favors its exclusion, we are likely to as well-but not without regret.

possible. Mark Pazniokas, Just One Hitch Before OK, House Adds 'Marriage' Definition, HaRTford Courant, Apr. 14, 2005, at A.1.

62. See Brune, supra note 59. Compare Press Release, AFL-CIO, Employment NonDiscrimination Act (ENDA) (June 24, 1999), http://www.aflcio.org/mediacenter/prsptm/ pr0624a1999.cfm ("[T]he AFL-CIO strongly urges Congress to pass the 'Employment NonDiscrimination Act (ENDA).' ") with Jeremy Bishop, An Injury To One Is An Injury To All, Trans Rights (Aug. 5, 2004), http://prideatwork.org/public/documents/press/2004/An\%20Injury\%20To\% 20One\%20Is\%20An\%20Injury\%20To\%20All,\%20Trans\%20Rights.pdf (arguing that the labor movement must require transgender protections in any employment discrimination legislation it supports).

63. Stefen Styrsky, Decision Day on Trans Rights: Human Rights Campaign Board Meets Amidst Growing Demand for Trans-inclusive Legislation, GAY CITY News, Aug. 5, 2004, http://www.gaycitynews.com/gen_332/decisiondayontrans.html.

64. See Kendall Thomas, Shower/Closet, 20 Assemblage 80 (1993).

65. See Human Rights Campaign foundation, Corporate Equality index: On Gay, Lesbian, Bisexual and Transgender Social Responsibility 14 (2004), http://www.hrc.org (follow "Publications" hyperlink; then follow "Corporate Equality Index" hyperlink; then follow "2004 Corporate Equality Index" hyperlink). 


\section{B. Healthcare Coverage}

Another dimension in which the license could be more ambitious, and go beyond ENDA, concerns healthcare coverage. The license could also mandate the provision of healthcare and other benefits for employees' samesex domestic partners. ${ }^{66}$ The mark might require this as a way of responding to the state's own discrimination in denying marriage to same-sex couples. In jurisdictions where same-sex couples cannot signal their commitment through civil marriage, they are unfairly harmed by employment policies that condition certain benefits upon civil marriage.

Employers that refuse to extend health benefits in this way could argue that they are treating all employees equally: gay or straight, employees receive family health benefits, but only if they are married. But such a response misses the point. This is not a case in which the harm arises from treating similarly-situated people differently. Instead, the harm results from treating differently-situated people the same, without regard for the background conditions of inequality that cause this treatment to affect them in different ways.

The trouble is that an employment policy extending health benefits to same-sex but not different-sex domestic partners could be seen as discriminating against heterosexuals, thus violating the nondiscrimination policy that forbids discrimination on the basis of sexual orientation. To mandate health benefits only for employees' same-sex domestic partners could be seen as a form of affirmative action-which would be inconsistent with ENDA and could allow critics to attack the license as granting gay and lesbian workers "special rights."

To avoid this reverse disparate treatment, the Fair Employment mark could require licensees to offer health benefits to employees' domestic partners, regardless of gender. Many companies have voluntarily achieved this standard already. Whether out of a corporate ethic of fairness to all employees, or out of a recognition that gay men and lesbians can be valuable employees worth recruiting, more and more companies are including domestic partners in employee benefits packages. In fact, recent studies show that more than 4000 U.S. companies offer their employees domestic-partner health benefits, including nearly half of the Fortune 500 companies. ${ }^{67}$ Thus, nothing in the license would prohibit an employer from doing what thou-

66. Some employers might also want to make these benefits available to employees' different-sex domestic partners, but in our view, an employer's decision not to cover different-sex domestic partners should not preclude use of the Fair Employment mark. Because different-sex couples have the option of marrying and thereby gaining employment benefits, while same-sex couples cannot (except in Massachusetts), it seems fair to include unmarried same-sex couples, but not unmarried different-sex couples in the benefits package. If the employer operates in a state that extends equal marriage rights to same-sex couples, the need for domestic partner benefits might similarly dissipate; discriminating on the basis of marital status need not have a disparate impact on gay people.

67. Daryl Herrschaft \& Kim I. Mills, Human Rights Campaign foundation, The State of the Workplace for Lesbian, Gay, Bisexual and Transgender Americans 2003 (2004), http://www.hrc.org (follow "Publications" hyperlink; then follow "State of the Workplace" hyperlink; then follow "State of the Workplace (1) 2003" hyperlink). 
sands of companies are already doing-granting all employees domesticpartner benefits. But to keep the mark's message focused on the most undisputable measure of equality, we have structured the license to retain ENDA's clarity. Paragraph 7 of the license expressly provides that the agreement "shall not be construed to require the provision of employee benefits to an individual for the benefit of the domestic partner of such individual."

\section{More Expansive Measures of Gay Friendliness}

Some readers might be thinking, "businesses already have a mark to signal employment policies that are fair to LGBT workers: the Human Rights Campaign Corporate Equality Index 100\% mark." True enough. Since 2002, HRC has been administering the Corporate Equality Index (CEI), a 100-point system that rates corporate policies and actions toward the lesbian, gay, bisexual, and transgender community. ${ }^{68}$ The CEI rates the Fortune 500 based upon the extent to which they:

- "Bar" discrimination on the basis of sexual orientation in their primary written nondiscrimination policy.

- Include the words "gender identity" or "gender identity and/or expression" in their primary written nondiscrimination policy.

- Offer health insurance coverage to employees' same-sex domestic partners firm-wide; or provide cash compensation to employees to purchase health insurance for a domestic partner on their own.

- Officially recognize and support a gay, lesbian, bisexual, and transgender employee resource group; or would support employees' forming a GLBT employee-resource group, if some expressed interest, by providing space and other resources; or have a firm-wide diversity council or working group whose mission specifically includes GLBT diversity.

- Offer diversity training that includes sexual orientation and/or gender identity and expression in the workplace.

- Engage in respectful and appropriate marketing to the gay, lesbian, bisexual, and transgender community and/or provide support through their corporate foundation or otherwise to GLBT health, educational, political, or community organizations or events.

- Engage in corporate action that would undermine the goal of equal rights for gay, lesbian, bisexual, and transgender people. ${ }^{69}$

68. Among its many advocacy activities on behalf of LGBT citizens, HRC administers the Corporate Equality Index through the Human Rights Campaign Foundation. See Human Rights Campaign Foundation, Corporate Equality Index, http://www.hrc.org (follow "Publications" hyperlink; then follow "Corporate Equality Index" hyperlink) (last visited Mar. 19, 2006).

69. HRC acquired "glvIndex" in 2001 and subsequently renamed it the HRC Corporate Equality Index survey. See Human Rights Campaign Foundation, CEI Non-Responders, http://www.hrc.org/Content/NavigationMenu/Work_Life/Get_Informed2/Corporate_Equality_Index Non_Responders/CEI_Non-Responders.htm (last visited Feb. 20, 2006). 
HRC uses its criteria to rate the companies on a 100-point scale, so that a company can achieve a relatively high score even if it cannot certify that it complies with all of the seven standards. Companies that achieve a score of $100 \%$ can use a "Corporate Equality Index 100 Percent" service mark on their products. Several companies, including American Airlines, Ford Motors, and PepsiCo, are HRC-mark licensees.

The Corporate Equality Index is an important and powerful measure of corporate responsibility to the LGBT community and its allies. The CEI has helped to move us to a point at which more than ninety-two percent of the Fortune 500 give their employees protection against sexual orientation discrimination. ${ }^{70}$ But in some important ways, the CEI is distinct from the Fair Employment mark.

The HRC 100\% mark is both more and less ambitious than the Fair Employment mark. It is less ambitious because it does not legally prohibit discrimination on the basis of sexual orientaticn. The HRC mark requires the employer to include sexual orientation in its nondiscrimination policy, but in many jurisdictions these policies do not constitute legally binding promises-especially with regard to applicants who are never hired (and therefore not in privity with the employer). ${ }^{71}$ In these jurisdictions, a nondiscrimination policy is "cheap talk" because employees and third parties gain no means to enforce violations of the policy. By transforming such policies into promises, the Fair Employment mark has enforcement "teeth" that the HRC $100 \%$ mark may lack, at least in some jurisdictions.

It is important to note, however, that even if the CEI does not by its terms ensure the level of ex ante protection guaranteed by the Fair Employment mark, the HRC does engage in quite vigorous ex post policing of the CEI. Teams of researchers at HRC scour litigation databases looking for actions involving employment discrimination by survey respondents. HRC then analyzes the firms' actions and positions in litigation to determine whether the firms are treating the cases with sufficient seriousness. This follow-up by HRC gives the survey respondents' nondiscrimination policies greater credibility. If an employer sought to defend allegations of employment discrimination on the ground that the "at-will" employment doctrine permitted its discriminatory action, HRC would respond with a lower CEI score the following year. The Fair Employment mark would reinforce this trend by giving additional, ex ante contractual teeth to firms' representations. When a firm violates its policy, HRC can punish it after the fact by lowering its CEI score, but if that same behavior breaks a Fair Employment mark promise, the victim can sue.

70. Equality Forum, Fortune 500 Nondiscrimination Project, http://www.equalityforum.org/ fortune500/ (last visited Nov. 9, 2005) (showing that 92.2 percent of the Fortune 500 give protection from sexual orientation discrimination in employment; site shows compliant and noncompliant firms by state and sector of the economy).

71. It still might be plausible to argue that an applicant entered into a preemployment contract-in exchange for the applicant's applying, the employer implicitly or explicitly promised not to discriminate. 
On several dimensions the $100 \%$ mark is more demanding than the Fair Employment mark. The CEI measures protection for gender identity and expression (omitted from the Fair Employment mark). The CEI also rewards the provision of domestic partner health benefits and encourages a variety of activities to support LGBT workers.

As noted above, there is no structural factor requiring an employer to choose either the CEI mark or the Fair Employment mark. The two marks move in consistent directions. It might be appropriate to have more than one mark to allow employers to signal different qualities. For the companies that work most progressively to ensure fairness to LGBT workers, the CEI represents a gold standard for corporate policymaking. But in a commercial environment where consumers and potential employees must sift through complex and sometimes conflicting information about companies and products, we do think there is some virtue in the Fair Employment mark's simplicity. ${ }^{72}$ That simplicity achieves distinct and valuable signaling, even in a world with the CEI. The Fair Employment mark is intentionally structured so that the public need not trust our bona fides or vigor in auditing compliance. The mark empowers employees and applicants to vindicate a clear wrong: discrimination on the basis of sexual orientation.

A specific criterion on the CEI scale that might cause concern is the one measuring the company's support for an LGBT employee group. The CEI survey makes clear that an employer can "support" an LGBT employee group in a variety of ways: by certifying that such a group exists and providing one contact person involved in the group, by funding the group's activities, or by providing meeting space. Some employers may be too small to support such a group, lacking a critical mass of openly LGBT employees. The CEI standards recognize this fact when they provide, as an alternative to support for an LGBT employee group, that a company could establish a senior level diversity council. Even the smallest company could fulfill this requirement.

Note, however, that the requirement of an LGBT employee group goes beyond the command of equality. It does more than place sexual orientation on par with race and gender in employment protections. LGBT employee groups and diversity councils are forms of affirmative action, as they represent affirmative steps to recruit and retain LGBT employees and make the workplace more comfortable for them. Our point is not to accept the equation of affirmative action with other forms of discrimination, but only to suggest that any requirement vulnerable to the "special rights" canard may weaken the mark's signal, at least for some consumers. A nondiscrimination requirement should never be removed, but remedial affirmative action and other forms of outreach might appropriately be subject to an ultimate sunset.

72. Our conclusion is tempered by our presumption of qualified deference to HRC, a highly credible and effective gay rights advocacy organization. In Straightforward, we suggest that individual supporters of gay rights-especially heterosexuals-should give qualified deference to gay rights organizations. See Ayres \& Brown, supra note 25, at 189-92 (2005). The Human Rights Campaign has done and continues to do heroic work in the struggle for equal employment rights. Our first inclination is to defer to their views on these matters. 
The CEI requirement of charitable contributions to LGBT organizations, sponsorship of LGBT events, or advertisements in LGBT publications might similarly draw the "special rights" criticism from some consumers and third parties. The financial factor could even strain the public's trust of HRC, because if contributions to HRC itself can satisfy this requirement, then HRC as an organization would become self-interested in the transaction. ${ }^{73}$

We have no reason to believe that HRC has acted in a self-interested manner in administering the CEI. Indeed, given the hostility that often meets initiatives promoting fairness for LGBT people, we find it necessary to make clear that our proposal should not be read as a criticism of HRC or the CEI. HRC has done great work in securing employment protections for LGBT workers. We stress the differences between the CEI and the Fair Employment mark only to demonstrate the distinct features of the mark.

The Fair Employment mark is designed to steer clear of any criticisms related to "special rights" or self-dealing. Since we do not collect a licensing fee, licensees and the public need not worry about whether we will be opportunistic with regard to certification or litigation. We certify only that a licensee has signed the license, and then we retire from the scene. There is no hint or possibility of personal profit, and thus our mark avoids the appearance of self-dealing.

We have considered whether the Fair Employment mark ought to incorporate a scoring system similar to the CEI. It would be possible to devise a mark that includes a numeral signaling the company's rating on an index similar to the CEI. Thus, for example, cereals made by General Mills might bear a label reading "FE=9," while cereals made by Kellogg would rate only " $\mathrm{FE}=7 .{ }^{, 74}$ This difference might provide some consumers a reason to buy Cheerios rather than Rice Krispies. But the example of General Mills and Kellogg suggests a reason not to combine the mark with a numerical rating. The difference between a "9" and a "7" may be insufficiently transparent to convey this difference to consumers.

For pragmatic reasons, we reject these varying signals. Consumers would not only have difficulty understanding a ratings system, but they

73. The Rev. Jesse Jackson and his civil rights organization, the Rainbow/PUSH Coalition, have been subject to this sort of critique. Some observers have accused them of giving companies charged with racial discrimination a sort of absolution in exchange for large donations to PUSH. See generally KenNeTh Timmerman, Shakedown: Exposing the Real Jesse Jackson (2003); Marc Morano, PUSH Comes to Shove: Jesse Jackson's Empire Crumbles, CNSNews.com, Jan. 15, 2002, available at http://www.newsmax.com/archives/articles/2002/1/14/170935.shtml.

74. General Mills could boast its higher Fair Employment rating because it has included sexual orientation in its nondiscrimination policy, offers domestic partner health insurance benefits, and has an LGBT Employee Group. These three factors-a nondiscrimination policy that covers sexual orientation, health benefits for domestic partners, and an LGBT employee group-are the easiest, most objective criteria to monitor, and General Mills has fulfilled all of them. Kellogg, on the other hand, offers only spotty domestic partner health benefits, which suppresses its score. See Human Rights Campaign Foundation, Profile: General Mills Inc., http://www.hrc.org/ Template.cfm?Section=Search_the_Database\&Template=/CustomSource/WorkNet/srch_dtl.cfm\& srchtype $=Q S \&$ searchid= $=1$ \&orgid $=1244$ (last visited Apr. 20, 2005); Human Rights Campaign Foundation, Profile: Kellogg Co., http:www.hrc.org/Template/cfm?Section=Search_the_Database\& Template $=/$ CustomSource/WorkNet/srch_dtl.cfm\&srchtype $=\mathrm{QS} \&$ searched $=1$ \&orgid $=1471$ (last visited Jan. 29, 2006). 
might also not equally endorse the varied commands of the CEI program. Instead, we have chosen-at least initially - to have a much simpler and limited coverage that is targeted at eradicating the core wrong, intentional disparate treatment on the basis of sexual orientation. To this end, we propose that the mark should be licensed only to companies that privately promise not to violate the ENDA commands of nondiscrimination.

One way to resolve the differences between the CEI approach and ours is through a kind of harmonization. HRC has already announced plans to update its index criteria in 2006. It will give increased weight to equal benefits, workplace policies for transgender employees, and diversity training. The simplest way to harmonize the CEI and the Fair Employment mark would be for HRC, as part of these updates, to make its criteria legally binding. ${ }^{75}$ By changing just two words, HRC might accomplish the major goal of the Fair Employment mark-granting employees private causes of action. All it would need to do is measure the extent to which the companies "bar employment discrimination based on sexual orientation by including the words 'sexual orientation' in their pally binding nondiscrimination or EEO policy." This change would substantially undercut the need for a separate Fair Employment mark. ${ }^{76}$

Harmonization is a two way street. It would also be possible for the Fair Employment mark to evolve so that it follows the contours of the HRC mark more closely. While our initial license only commits companies to the nondiscrimination mandates of ENDA, subsequent editions of the mark might encompass more far-reaching goals. For example, once ENDA is enacted, the license would be wholly redundant with the mandated federal right. At that point in time, it might be appropriate to require that licensees provide domestic-partnership benefits (at least to same-sex partners, who are denied the option to marry civilly). Alternatively, it might be appropriate to add gender identity and expression to the covered protections. In the spirit of incrementalism that informs much of our thinking, ${ }^{77}$ we endorse the possibility of evolving rights. But we should be careful not to impose an ever-

75. The same point could be made about another recent HRC innovation: the Congressional Non-Discrimination Pledge. HRC, along with the Gender Public Advocacy Coalition and other allied organizations, has secured "commitments from members of Congress not to discriminate based on sexual orientation and gender identity and expression in their personal offices." Human Rights Campaign Foundation, Members of 108th Congress With Sexual Orientation and Gender Identity and Expression Inclusive Non-Discrimination Pledges, http://www.hrc.org/Content/NavigationMenu/ HRC/Get_Informed/Issues/Workplace_Discrimination/Background_Information4/Pledge_Project.htm (last visited Apr. 22, 2005) (emphasis added). To make the pledge, members of Congress must sign the following statement: "The sexual orientation and gender identity or expression of an individual is not a consideration in the hiring, promoting or terminating of an employee in my office." Id. We are thrilled to see that 21 Senators and 124 Representatives (15 Republicans, 128 Democrats) have signed the pledge. Id. Again, however, we worry that "statements" and "commitments" fall short of enforceable promises. The symbolic value is great, but for an LGBT employee who actually suffers discrimination, the pledge may prove toothless.

76. The only question would be whether the additional "special rights" features chilled acceptance to the point where it might be worthwhile to have a separate mark that solely prohibited discrimination.

77. See AYres \& Brown, supra note 25 , at 84 . 
escalating set of duties on employers. Corporations will be chary of the mark if they can predict that it will become increasingly burdensome (because there will be costs in adverse publicity if in the future they choose to discontinue their use of the mark). HRC appears to recognize the importance of such stability. In the 2005 survey, they gave firms explicit, written notice of changes scheduled to take effect in 2006.

\section{Covering Affiliate Corporations}

Finally, it might be appropriate to require users of the mark to certify that affiliated corporations-particularly major suppliers-have also agreed to be bound by the nondiscrimination mandate of the mark. Other labeling schemes have dealt more rigorously than our license has with the problem of suppliers. For example, the "leaping bunny" mark of the Coalition for Consumer Information on Cosmetics (CCIC) certifies that both the manufacturer and the ingredient suppliers for marked cosmetics and household products do not perform tests on animals. ${ }^{78}$

In order to ensure a critical level of participation, we have crafted the Fair Employment license only to apply to the licensee's own employment practices. Again, this mimics the coverage of ENDA itself, because corporations are not responsible for discriminatory practices of their suppliers. Of course, one danger of this is that an essentially empty "gay friendly" shell could be devised to bear the label, while the entire manufacturing process is conducted by companies that discriminate against gay, lesbian, and bisexual employees. But we find it unlikely that corporate forms will be manipulated because of the possibility of disparate-treatment liability, and we are reluctant to require an adopting company to enforce nondiscrimination up the supply chain (at least in the first iteration of the mark).

\section{E. Group Enforcement}

The potential victims of discrimination are the most obvious group of enforcers. The certification license expressly empowers this group by naming the corporation's employees and applicants as third-party beneficiaries and clothing them with the same kind of private action rights they would have under ENDA: "The Licensee and Licensor intend that these third-party beneficiaries will have the right to sue the Licensee for any breach of this agreement and have a legal right to the same remedies (including damages and injunctive relief) to which they would be entitled if ENDA were in effect." Gay and lesbian employees will have the strongest incentives to police the licensee's conduct, and the cheapest access to information regarding violations. Therefore, using the licensing agreement to create rights of action in the employees-who are, after all, the intended beneficiaries of the whole arrangement-is eminently sensible.

78. The Coalition for Consumer Information on Cosmetics, Frequently Asked Questions, http://www.leapingbunny.org/faq.htm (last visited May 21, 2004). 
For current or potential employees to assist in enforcement efforts, they must know about the mark and the rights it guarantees. Some licensees might use the mark to promote their products with consumers but not alert employees to its meaning. We doubt that this is a serious concern, however. As argued below, many employers will use the mark as a tool to recruit potential employees who are gay, lesbian, or bisexual. Moreover, gay and lesbian employees have good incentives to learn about the nondiscrimination policies of their actual or potential employers. The names of all licensees will be publicly available on the Internet. Gay rights advocacy groups such as HRC are likely to continue to provide information about the policies of individual employers. Some employers may not be motivated to distribute this information to employees on their own. But gay workers are likely to learn very quickly when their employer has chosen to start marking its product.

Certification marks usually involve the licensor as an active monitor in certifying the compliance of the mark user. The mark users pay license fees to the licensor to cover these monitoring expenses. But we have opted for a much more decentralized structure that obviates the need for monitoring by the licensor and the payment of licensing fees. The licensor merely certifies that the licensee has promised not to discriminate. This certification does not require licensor effort, because the very act of validly using the mark constitutes the promise of nondiscrimination. The employees of the licensee are then left (just as under ENDA) to do the substantive work of enforcing the underlying promise.

Far more complex enforcement schemes than the Fair Employment mark have succeeded with regard to other certification marks. For example, consider the "Orthodox Union" emblem (a letter " $U$ " inside a larger circle or letter " $\mathrm{O}$ ") certifying that a product is kosher. ${ }^{79}$ The Orthodox Union certification service employs a staff of "over 1,000 rabbinic coordinators, kashruth supervisors, food chemists and support personnel.,80 It certifies " 250,000 brand names, hotels, restaurants, services and 2,505 companies in 54 countries around the globe., ${ }^{, 81}$ Substantial paperwork and close attention to detail are required of companies using the OU emblem. ${ }^{82}$ In contrast, the Fair Employment mark is a model of procedural licensing simplicity.

An alternative way of supplementing private employee enforcement would be to specify that particular gay rights advocacy organizations would have standing as third-party beneficiaries to enforce the agreement. Such

79. Orthodox Union, OU Kosher Policy Information, http://www.ou.org/kosher/policy.htm (last visited May 21, 2004).

80. Orthodox Union, About the Orthodox Union, http:/www.ou.org/about/ou.htm (last visited May 21, 2004).

81. Id.

82. The website of the Orthodox Union carries a short article that illustrates the complexity of compliance. See Orthodox Union, Is Your Kosher Program Running Smoothly?, http://www.ou.org/ kosher/behindsymbol/kosherprog.htm (last visited May 21, 2004). 
organizations have standing to enforce other civil rights laws, ${ }^{83}$ and extending such enforcement powers might be particularly appropriate when government enforcement is not forthcoming. Indeed, if an organization such as the Human Rights Campaign or its Worknet division were to act as the licensor itself, it would have direct standing as a certifier to ensure that its licensees were complying with the promises of the license. Even if HRC did not act as licensor, it might be listed as a third-party beneficiary of the agreement, again creating the right to enforce the standards of fairness in employment contained in the agreement.

The power of advocacy groups is also related to the question of auditing. To facilitate enforcement by agencies and organizations, the licensing agreement could require the licensee company to permit "testing"-what some might call "deceptive audits"-by which people who do not really intend to take jobs or remain in jobs pose as applicants or employees to test the company's compliance with the licensing agreement. Testing is used regularly in making sure that minorities are not discriminated against in federal housing programs. States also use testing to judge stores' compliance with laws against the purchase of alcohol or cigarettes by minors. Similarly, here testers could apply for a posted job opening and present themselves as openly bisexual, gay, or lesbian. They could ask about discrimination policies, domestic partner benefits, or LGBT employee groups. They might even take the jobs temporarily, without a bona fide intention of working for the company, just to see whether the policies are actually followed once employees enter the company.

Corporate consent to potential auditing is important because it can reduce the risk that the auditor will be sued by the corporation. In one case, a company subject to similar testing sued and obtained a large jury verdict against the testing entity. In Food Lion v. Capital Cities, Food Lion brought a tort action when $\mathrm{ABC}$ broadcast videotape of unwholesome food handling practices. ${ }^{84}$ The videotape had been obtained by $A B C$ reporters who gained employment in Food Lion supermarkets by misrepresentation. ${ }^{85}$ The plaintiff alleged fraud, employee disloyalty, and unfair trade practices. The jury returned a verdict for the plaintiff, awarding $\$ 1,402$ in compensatory damages and over $\$ 5$ million in punitive damages, which the trial judge reduced to $\$ 315,000$ through remittitur. ${ }^{86}$ On appeal, the court rejected Food Lion's fraud claim, because the reporters were at-will employees for an indefinite period, and Food Lion could show no reliance on their misrepresentations in training them and paying their wages. ${ }^{87}$ With respect to the claims of employee disloyalty, however, the court held that the reporters intended to act

83. Havens Realty Corp. v. Coleman, 455 U.S. 363, 372-79 (1982) (giving standing to civilrights organization to sue as fair-housing plaintiff).

84. Food Lion, Inc. v. Capital Cities/ABC, Inc., 984 F. Supp. 923,927 (M.D.N.C. 1997).

85. Id.

86. Food Lion, Inc. v. Capital Cities/ABC, Inc., 194 F.3d 505, 510 (4th Cir. 1999).

87. Id. at 513-14. 
against the interests of the plaintiff and were liable in tort. ${ }^{88}$ The reporters' disloyalty also caused the reporters to exceed the consent Food Lion granted them to enter plaintiff's premises; the reporters therefore committed trespass. ${ }^{89}$ The court rejected Food Lion's claim that misrepresentations on the job applications alone could vitiate Food Lion's consent.

To avoid anything resembling the Food Lion case, the entity licensing the Fair Employment mark might include in the licensing agreement a clause making clear that use of the mark is conditioned upon consent to random testing. This could create incentives for licensees to comply with the mark's requirements, and in the event testing did occur, preempt any claims of fraud or trespass they might bring arising from the testing.

Although there are strong arguments for empowering advocacy groups like HRC both to audit and to bring suit against licensees, we have chosen, in the spirit of incrementalism, to maintain a narrow set of potential plaintiffs and enforcement tools for the initial version of the license. Real progress can be made just by endowing the direct victims of discrimination with a power to sue. And to our minds, the costs of scaring away potential licensees could outweigh these concrete benefits if the licensing scheme becomes too ambitious or complex. By expressly waiving any right to sue for violations of the nondiscrimination promise, our license agreement makes clear that our attitudes toward enforcement are inconsequential. Our transparent passivity is one less thing for employers to worry about when deciding whether to commit to the license.

A more modest alternative would be to use a group enforcement system as a substitute for individual enforcement. Instead of our proposed system of private causes of action with damages and no auditing, one could instead have a system of vigorous auditing and no damages. Under this alternative, loss of the mark would be the only consequence of discriminating. Potential licensees would not have to worry about potential dollar damages for violating the nondiscrimination promise because the only consequence of such a finding would be loss of the mark. As a remedial matter, this alternative is close to the structure of the HRC $100 \%$ mark. The HRC takes responsibility for judging compliance and the consequences of negative assessments are purely informational-loss of the mark and negative publicity. While this represents a plausible incremental alternative, we prefer replicating ENDA rights with legally binding causes of action-at least to the extent that we can induce a substantial number of employers to sign. The next Section will argue that it is plausible to expect that a substantial number of employers may be willing to sign.

88. Id. at 515-16.

89. Id. at 516-19.

90. Id. at 518 . 


\section{MARKETING Nondiscrimination}

This Section takes on the hard question of why a company might be willing to sign up for potential legal liability. One response to the mark is that it is a nonstarter because no competent general counsel would ever allow a company to volunteer for liability. But this is surely wrong as a matter of a priori theory. Every contract-every promise, every warranty, every representation of fact-volunteers for potential legal liability. Business is the art of calculated volunteering and risk-taking, and the crucial empirical question is whether the benefits of licensing the mark will ever outweigh the costs.

This Section explores the potential benefits of licensing. In large part these will be the marketing benefits of being seen as a non-discriminator. But the Section is also about marketing in a second sense. We are also interested in identifying the set of employers to whom we might be able to market the licensing agreement. This is not just a theoretical exercise. The publication of this Article kicks off our campaign to cover 100,000 employees by the end of 2007. This Section attempts to develop a positive theory that identifies the conditions under which an employer's benefits are likely to outweigh its costs of adoption. We will ultimately identify a number of factors that suggest that the most likely signatories are employers that

- are located in one of the seventeen states with statutes that already grant private rights of action for sexual orientation discrimination;

- have independently included sexual orientation in their nondiscrimination policy or have publicly announced support for ENDA;

- sell to government entities requiring contractors not to discriminate on the basis of sexual orientation; or

- have smaller market shares.

The first two characteristics describe employers that face smaller additional costs of signing, while the last (smaller market share) describes an employer for which we predict the net gains in demand will be particularly high.

\section{A. The Incremental Costs}

As an initial matter, it is important to get a handle on the magnitude of the potential litigation risk for companies that become licensees. Earlier we emphasized that the experience of licensees themselves would provide valuable information on the likely litigation rates that one might see under ENDA. But it turns out that the United States General Accounting Office (GAO) has already compiled valuable information on the number of complaints filed under state statutes that prohibit employment discrimination on the basis of sexual orientation. ${ }^{91}$ In 2000 , the GAO analyzed the claim rates

91. U.S. Gen. Accounting Office, Publ'n No. GaO/OGC-00-27R, SexualOrientation-Based Employment Discrimination: States' Experience with Statutory ProHIBITIONS SINCE 1997 (2000). 
in eleven states with statutory prohibitions. ${ }^{92}$ The study reported the number of claims of sexual orientation discrimination made in each state in each year. But the study failed to analyze the rate of claiming relative to the number of employees in each state. ${ }^{93}$ When we combine the GAO claim data with information from the Bureau of Labor Statistics on yearly levels of state employment, we can more directly assess the incremental litigation risk created by prohibitions on sexual orientation discrimination. ${ }^{94}$

\section{TABLE I:}

ANALYSIS of Litigation RATES and EXPECTED Costs of State Prohibitions

\begin{tabular}{|c|c|c|c|c|c|}
\hline & $\begin{array}{c}\text { Employees } \\
\text { Per } \\
\text { Complaint }\end{array}$ & $\begin{array}{c}\text { Gay } \\
\text { Employees } \\
\text { Per } \\
\text { Complaint }\end{array}$ & $\begin{array}{c}\% \text { of Gay } \\
\text { Employees } \\
\text { Filing } \\
\text { Complaints }\end{array}$ & $\begin{array}{l}\text { Cost Per } \\
\text { Employee }\end{array}$ & $\begin{array}{l}\text { Cost Per } \\
\text { Gay } \\
\text { Employee }\end{array}$ \\
\hline Average & 59,739 & 1792 & $0.06 \%$ & $\$ 1.67$ & $\$ 55.80$ \\
\hline Maximum & 294,550 & 8,837 & $0.18 \%$ & $\$ 5.32$ & $\$ 177.22$ \\
\hline Minimum & 18,809 & 564 & $0.01 \%$ & $\$ 0.34$ & $\$ 11.32$ \\
\hline $\begin{array}{l}\text { Standard } \\
\text { Division }\end{array}$ & 55,309 & 1,569 & $0.04 \%$ & $\$ 1.23$ & $\$ 41.09$ \\
\hline \multicolumn{6}{|c|}{$\begin{array}{l}\text { Notes: Complaint Data taken from GAO Report, supra note } 91 \text {; Employment Data taken from } \\
\text { Bureau of Labor Statistics Report, infra note } 94 \text {. In the end, there were sixty-seven state-year } \\
\text { observations. "Gay Employee" calculations assume three percent of employees are gay or } \\
\text { lesbian. "Cost" calculations assume that an employer expects the average complaint to cost } \\
\$ 100,000 \text {. }\end{array}$} \\
\hline
\end{tabular}

Table 1 shows the results of the analysis. We find that overall the rate of complaining is relatively low. Averaging over the sixty-seven state-year observations in the data, we find almost 60,000 workers for every sexual orientation complaint filed. The second column recalculates the complaint

92. Id. at 7 (these were the states that had claim data available).

93. It instead calculated the proportion of state discrimination complaints that were based on claims of sexual orientation. Under this analysis, one finds that Vermont experienced a higher proportion of sexual orientation complaints than other states. But this might be an artifact of Vermont having fewer racial and ethnic minority workers than other states. It does not tell us about the expected additional risk that employers face in Vermont because of the employment protections for gay workers. See William N. Eskridge \& Nan D. Hunter, Sexuality, Gender, and the Law 869 (2d ed. 2004); see also William Rubenstein, Do Gay Rights Laws Matter? An Empirical Assessment, 75 So. CAL. L. REv. 65 (2001) (arguing that, assuming lesbians and gay men comprise five percent of the population, rate of sexual orientation discrimination complaints roughly parallels rate of sex discrimination complaints). William Eskridge and Nan Hunter have noted that the GAO data "raise as many questions [as] they answer." EsKRIDGE \& HUNTER, supra, at 894. For example, the number of complaints of sexual orientation discrimination does not correspond to total populations (California had actual numbers similar to Massachusetts, which had only one-fifth as many residents, while Wisconsin, the state whose population is closest to Massachusetts, had fewer than one-half the number of complaints filed). See id. at 869.

94. See U.S. Department of Labor, Bureau of Labor Statistics, Employment, Hours, and Earnings from the Current Employment Statistics Survey, http://data.bls.gov/PDQ/ outside.jsp?survey=sm (last visited Feb. 21, 2006), for the number-of-employees figures. The employment number used is the total number of non-agricultural employees for a given state in a given year. Employment numbers are given on a monthly basis, so we used the average monthly employment for our annual data. 
rate in terms of gay employees-arbitrarily assuming that three percent of all employees are gay or lesbian. ${ }^{95}$ The analysis suggests that in an average year only one out of every 1792 gay employees filed a complaint. In other words, the probability that a gay employee will file a sexual orientation charge in any year is six-tenths of one percent.

To give an idea of the economic costs to employers of such complaints, Table 1 also reports the average costs per employee, assuming that the expected average costs for an employer of responding to a complaint (including costs of diverted attention, attorney fees, legal damages, and so forth) is $\$ 100,000$. This is a ballpark estimate (possibly generous) that is only an attempt to measure the probable magnitude of the costs of this new type of liability. Table 1 suggests that the overall costs to date have been low. The average cost of these laws per employee is less than $\$ 2$ per year $(\$ 1.67)$.

The final column of Table 1 calculates the expected annual costs per gay employee. Here we see a more substantial average cost: about $\$ 56$ per year. On net, for each additional year a statute has been in effect, the expected annual cost per employee rises by 9.7 cents.

This analysis suggests that the state statutes have not substantially increased the overall wage bill. Measured on a per-employee or a per-gayemployee basis, it is hard to think that the costs of responding to litigation complaints are driving employer resistance to making binding nondiscrimination promises. ${ }^{97}$

Concerns about added litigation expense provide an even weaker excuse for employers in places that prohibit sexual orientation discrimination in employment by state statute. There are currently seventeen states (including the District of Columbia) that legislatively prohibit such discrimination.

95. See Jennifer Gerarda Brown, Competitive Federalism and the Legislative Incentives to Recognize Same-Sex Marriage, 68 So. CAL. L. Rev. 745, 776-79 (1995) (conservatively adopting three percent, based upon surveys and other social scientific research). The point of this exercise is to give an estimate for the magnitude of the rate. Since the second column is merely the first column multiplied by the proportion of workers who are gay, readers can easily calculate claim rates based on alternative assumptions.

96. An Ordinary Least Squares regression of the annual costs per employee on a variety of factors suggests that the general cost is decreasing over time, but for each state, costs increase the longer the law is in effect. The regression controlled for "year of the observation," "years law has been in effect in this state" and ten state dummy variables. The background data and analysis is publicly downloadable at http://islandia.law.yale.edu/ayres/Analysis\%20of\%20GAO\%20Data\% 20Concern\%20Sexual\%200rtn\%20Disc\%20Statutes.xls.

97. We will consider whether the threat of consumer boycotts provides an alternative cost basis. Infra Section III.C.

98. According to the National Gay and Lesbian Task Force, $47 \%$ of the U.S. population lives in jurisdictions that have adopted nondiscrimination laws. This includes $38 \%$ who live in states with such laws; another $9 \%$ are covered by city or county law. See SeAN CaHILl, The Glass Nearly Half Full: $47 \%$ of U.S. Population Lives in Jurisdiction with Sexual Orientation NonDISCRIMINATION LAW 3-4 (2005), http://www.thetaskforce.org/downloads/GlassHalfFull.pdf. The states are California, Connecticut, the District of Columbia, Hawaii, Illinois, Maine, Maryland, Massachusetts, Minnesota, Nevada, New Hampshire, New Jersey, New Mexico, Rhode Island, Vermont, Washington, and Wisconsin. See Human Rights Campaign Foundation, Non-Discrimination Laws: State-by-State, http://www.hrc.org (follow "Laws in Your State" hyperlink; then follow "Statewide Anti-discrimination Laws and Policies" hyperlink) (last visited Feb. 22, 2006). 
Adopting the mark exposes employers in these states to no additional liability, because they are independently amenable to suit under the state analogue to the license. Indeed, the laws in many of these states are more expansive than the Fair Employment mark duties because they include the possibility of punitive damages, expose employers to potential disparateimpact claims, or have been interpreted to cover gender identity and expression. ${ }^{99}$ The marginal benefits of protecting workers in these states with the Fair Employment mark are greatly reduced, but so too are the marginal costs of providing this contractual coverage.

A similar argument applies to employers that have independently included sexual orientation within their nondiscrimination policy. Employers that have already committed themselves not to discriminate on the basis of sexual orientation have little to lose in the way of legal liability by signing the Fair Employment license. But the issue is complicated by the uncertain legal effect of nondiscrimination policies. It might come as a surprise to some readers, but in some jurisdictions the majestic language of "policies" does not give rise to legally binding "promises." Employers that include sexual orientation in their nondiscrimination policies have been known to turn around and claim that they have no legal duty not to discriminate-and they sometimes win.

Cases considering the contractual enforceability of nondiscrimination provisions in employee handbooks and company policies follow a somewhat similar structure. They start with the at-will presumption, namely that an employment relationship is presumed to be terminable at will on both sides. Sometimes, courts go on to rule that handbooks or policies can create enforceable obligations (typically by establishing specific procedures or criteria for termination). In a smaller number of cases, the courts consider whether the specific nondiscrimination provision at issue is enforceable.

Some courts have held that even very clear language in an employee handbook (e.g., "No employee shall be dismissed without just cause") was unenforceable under contract because it did not meet the traditional requirements of contract formation. ${ }^{100}$ For example, in Joachim v. AT\&T

99. See, e.g., Assemb. B. 2900, 2004 Assemb., Reg. Sess. (Cal. 2004) (amending existing labor and employment nondiscrimination provisions in California law to be consistent with the nondiscrimination provisions of the Fair Employment and Housing Act (FEHA), including prohibitions on discrimination on the basis of gender identity); Assemb. B. 196, 2003 Assemb., Reg. Sess. (Cal. 2003) (amending Fair Employment and Housing law to include gender identity and gender status); N.J. STAT. ANN. $\$ 10: 5-1$ (West 2002); N.Y. EXEc. LAW \$§ 290-300 (McKinney 2005); see also Equality California, AB 2900: The Omnibus Labor and Employment Non-Discrimination Act, http://www.eqca.org/atf/cf/\{687DF34F-6480-4BCD-9C2B-1F33FD8E1294\}/AB_2900_factsheet.pdf (last visited Apr. 25, 2005); New Jersey Office of the Attorney General, Division of Civil Rights: Employment, http://www.state.nj.us/lps/dcr/employ.html (last visited Apr. 25, 2005) (explaining that the New Jersey Law Against Discrimination includes disparate impact claims). See generally National Gay \& Lesbian Task Force, Scope of Explicitly Transgender-Inclusive Anti-Discrimination Laws, http://www.transgenderlaw.org/ndlaws/ngltftlpichart.pdf (last visited Apr. 25, 2005) (listing states and towns with employment protections for transgendered people).

100. Joachim v. AT\&T Info. Sys., 793 F.2d 113 (5th Cir. 1986) (per curiam) (quoting Reynolds Mfg. Co. v. Mendoza, 644 S.W.2d 536, 539 (Tex. App. 1982)) (holding that although AT\&T's personnel handbook said that sexual orientation would not be used as a basis for job discrimination or termination and plaintiff alleged that he was terminated because he was gay, "employee hand- 
Information Systems, the Fifth Circuit affirmed summary judgment against a plaintiff who invoked the employer's handbook when complaining of sexual orientation discrimination, because the court concluded that the handbook did not form a contract. ${ }^{10}$

The issue is complicated because the legal enforceability of nondiscrimination policies (and employee handbooks more generally) is in flux. Some courts have held that nondiscrimination provisions can give rise to enforceable obligations. ${ }^{102}$ For example, Albertus Magnus College was unable to persuade a federal district court in 2000 that its nondiscrimination policy was not an enforceable contract under state law. ${ }^{103}$

Arizona has an open-ended test that relies heavily on particular facts to determine whether handbook language is enforceable. This test is motivated by the policy that if "an employer does choose to issue a policy statement, in a manual or otherwise, and, by its language or by the employer's actions, encourages reliance thereon, the employer cannot be free to only selectively

books 'constituted no more than general guidelines,' and did not create a contractual right in the employees”); Johnson v. Nat'l Beef Packing Co., 551 P.2d 779, 781-82 (Kan. 1976) (holding that although company policy manual said, "No employee shall be dismissed without just cause," "[i]t was only a unilateral expression of company policy and procedures. Its terms were not bargained for by the parties and any benefits conferred by it were mere gratuities. Certainly, no meeting of the minds was evidenced by the defendant's unilateral act of publishing company policy."); Poree v. Lakewind E. Apartments, Civ. A. No. 93-3466, 1994 WL 705428, at *2 (E.D. La. Dec. 15, 1994) (deciding that although employee handbook described a company policy of nondiscrimination and plaintiff alleged racial discrimination in violation of that policy, complaint was dismissed because "under Louisiana law, employee handbooks and personnel policy manuals do not in themselves create contractual rights between the employer and employee"); Hillie v. Mutual of Omaha Ins. Co., 512 N.W.2d 358, 362 (Neb. 1994) (suggesting that any language in a handbook that reserves discretion in the employer to (a) follow handbook procedures, or (b) fire the employee at will has effect of negating the existence of a contractual promise not to discriminate); Morosetti v. La. Land and Exploration Co., 564 A.2d 151, 153 ( $\mathrm{Pa}$. 1989) (holding that when company circulated a severance pay policy, but later denied severance pay to several employees, there was no contract because a "company may indeed have a policy upon which they intend to act, given certain circumstances or events, but unless they communicate that policy as part of a definite offer of employment they are free to change as events may require").

101. See Joachim, 793 F.2d at 114.

102. See, e.g., Black v. Baker Oil Tools, Inc., 107 F.3d 1457, 1462 (10th Cir. 1997) (holding that "the promise that '[a]ll relations and decisions pertaining to employment ... [and] terminations ... will be executed without regard to ... physical ... handicap ....' is more than a mere 'vague assurance' or 'puffery,' but rather is a 'substantive restriction' on Baker Oil's ability to terminate its employees;" still, plaintiff must give consideration for this obligation); Adleta v. Gen. Elec., No. C1-94-559, 1996 WL 365783, at *4-5 (S.D. Ohio May 28, 1996) (“Ohio appears to recognize a cause of action based upon a company's employment policies and procedures .... In order to create a binding obligation, these representations must satisfy the traditional elements of contract lawnamely, offer, acceptance and consideration."); Johnson v. Celsius Energy Co., No. C88-0227-13, 1989 WL 260154, at *4 (D. Wyo. Feb. 28, 1989) (holding that when defendant's employee handbook "prohibits unlawful discrimination in all aspects and conditions of employment, including hiring, training, advancement, compensation, transfers, benefits, and terminations," such language negates employment at-will because it "creates an expectation on the part of an employee that [the provision] will be followed, inducing an employee to continue his employment," thereby negating "employment at-will") (emphasis added) (citations and internal quotation marks omitted).

103. Hartwig v. Albertus Magnus Coll., 93 F. Supp. 2d 200 (D. Conn. 2000); see also Durham Life Ins. Co. v. Evans, No. CIV.A.94-0801, 1994 WL 447406, at *2-3 (E.D. Pa. Aug. 19, 1994) (allowing employee's claim for breach of contract in sexual harassment suit to proceed), aff'd, 39 F.3d 1169 (3d Cir. 1994). 
abide by it. Having announced a policy, the employer may not treat it as illusory." ${ }^{, 104}$ California also has an open-ended, multifactor test examining "the totality of the circumstances .... Every case thus turns on its own facts." ${ }^{105}$ Massachusetts recently liberalized its test for determining whether company policies can give rise to contractual obligations, finding contractual language in a personnel manual because it " $\mathrm{g}[\mathrm{a}] \mathrm{ve}$ each employee the right to expect that she will be treated fairly" even though there was no express language guaranteeing discharge only for cause. ${ }^{100}$

Like the court in Arizona, the Massachusetts Supreme Court was driven by a desire for fundamental fairness:

Management distributes personnel manuals because it is thought to be in its best interests to do so. Such a practice encourages employee security, satisfaction, and loyalty and a sense that every employee will be treated fairly and equally. Management expects that employees will adhere to the obligations that the manual sets forth. Courts recently have been reluctant to permit management to reap the benefits of a personnel manual and at the same time avoid promises freely made in the manual that employees reasonably believed were part of their arrangement with the employer. Management voluntarily offers, and defines the terms of, any benefit set forth in its unbargained for personnel manual. The employees may have a reasonable expectancy that management will adhere to a manual's provisions. ${ }^{107}$

Although one federal court recently applied New Jersey law to rule nondiscrimination provisions unenforceable, the New Jersey Supreme Court has found handbook language enforceable when such language is definite and promissory (for example, "efforts will be made to take one or more of the following measures"). ${ }^{108}$ This language even overrode an express disclaimer found elsewhere in the handbook. ${ }^{105}$

The trend is moving away from requiring that the employee knew or relied on the policy. ${ }^{10}$ But courts still at times refuse to enforce

104. Leikvold v. Valley View Cmty. Hosp., 688 P.2d 170, 174 (Ariz. 1984). It should be noted that the employee's reliance is not necessary: it is "only one of several factors that are relevant in determining whether a particular policy was intended by the parties to modify an at-will agreement." Wagenseller v. Scottsdale Mem'l Hosp., 710 P.2d 1025, 1038 (Ariz. 1985).

105. Guz v. Bechtel Nat'l, Inc., 8 P.3d 1089, 1101 (Cal. 2000) (citations and internal quotation marks omitted).

106. O'Brien v. New England Tel. \& Tel. Co., 664 N.E.2d 843, 849 (Mass. 1996).

107. Id. at 848-49 (citation omitted).

108. Geldreich v. Am. Cyanamid Co., 691 A.2d 423, 427 (N.J. 1997).

109. Id.

110. See, e.8., Marfia v. T.C. Ziraat Bankasi, 903 F. Supp. 463, 470 (S.D.N.Y. 1995) (holding the employer bank's "Non-Discrimination Policy" set forth in employee manual "surely can be read as a contractual limitation on the Bank's ability to discharge employees for discriminatory reasons”). But see Gruver v. Ezon Prods., Inc., 763 F. Supp. 772, 774 (M.D. Pa. 1991) (deciding that to establish contractual violation, employee must establish that harassment policy in personnel manual induced her employment). 
nondiscrimination policies because they find that the policies were too vague or were not intended to be legally enforceable."'

Nondiscrimination policies may also fail to cover discrimination against rejected applicants. Since the rejected applicant is not hired, courts find no enforceable promise between the applicant and the employer. Applicants may argue that even if there is not an employment contract, there was an independent application contract whereby the applicant agreed to apply in return for the employer's promise to consider the application on a nondiscriminatory basis. But courts might resurrect the requirement that the applicant knew and actually relied on the employer policy. In contrast, the Fair Employment mark license expressly grants rejected applicants rights to sue for discrimination. Rejected applicants thus represent another divergence in potential legal risk even for employers that have included sexual orientation in their nondiscrimination policy.

At the moment, the most that one can say is that employer nondiscrimination policies are only probabilistically enforceable. The magnitude of the probability depends upon the jurisdiction, whether the plaintiff is an applicant or an employee, and details of how the policy was promulgated and presented. The Fair Employment mark represents a real gain for civil rights because it grants employees certain, as opposed to uncertain, rights to sue. The flip side of that coin, however, is that adopting the mark exposes some employers to higher potential liability. But since any employer that has voluntarily included sexual orientation in its nondiscrimination clause already faces some prospect of litigation, employers with inclusive nondiscrimination policies have relatively less to fear in terms of litigation from signing the license.

Employer willingness-to-sign will of course turn on the benefits as well as these costs of signing. An analysis of litigation experience under state nondiscrimination statutes suggests that the litigation risk incurred by signing is in fact rather low. Moreover, employers that are bound by these state statutes or by their own voluntary policies of nondiscrimination have even less reason to resist committing to nondiscrimination. Employers may worry instead that adopting the mark will expose them to consumer boycotts that will reduce the demand for their products. We expressly address this concern below. But the idea of added litigation risk is not a conversation stopper, if employers rationally assess its true magnitude.

\section{B. Risk Management}

Indeed, some employers might adopt the mark specifically to contain their potential liability for discrimination. This seems paradoxical, certainly: how could volunteering for liability ever reduce risk? The answer lies in the probabilistic enforcement currently given to nondiscrimination policies, as outlined above. As Ian Ayres and Richard Ober argue, "Increasingly courts

111. E.g., Blaise-Williams v. Sumitomo Bank Ltd., 592 N.Y.S.2d 41, 42 (App. Div. 1993) (ruling that general antidiscrimination statement in handbook was too vague to be enforceable). 
are interpreting these nondiscrimination policies to be nondiscrimination promises. And when they do, they can impose open-ended forms of liability." "12 A move from "policies" to explicit "promises" is prudent because it can give employers more control over their potential exposure. As Ayres and Ober explain, a policy that prohibits "discrimination" might be interpreted to give employees both "disparate treatment" and "disparate impact" causes of action. ${ }^{1 / 3}$ The Fair Employment mark license contains potential liability by expressly limiting plaintiffs' theories of discrimination to disparate treatment.

Similarly, the Fair Employment mark license gives employers procedural safeguards. Employees are required to give notice of claims within 180 days of the occurrence. Also important, the Fair Employment mark license can be used in conjunction with an arbitration clause in employee contracts. Instead of leaving potential liability up to the judicial coin toss of nondiscrimination policies, some employers might prefer to commit to nondiscrimination in a way that is enforceable and clearly defined.

\section{Satisfying Input Demand}

The next Section will assess the impact of the mark on consumer demand. But before doing that, it is useful to assess the impact of the license on the flow of various inputs to a firm. Most basically, adopting the Fair Employment mark may be an attractive mechanism for recruiting gay and lesbian employees. Members of the gay community have strong incentives to learn about the nondiscrimination policies of prospective employers and, other things being equal, are likely to prefer employers that promise not to discriminate. Some employers may even prefer the mark to the passage of ENDA because it gives them a means of meaningfully distinguishing themselves from other employers.

The Fair Employment mark is particularly helpful here because it is something that the employer commits to before it negotiates contracts with individual employees. Employees who value nondiscrimination may be reluctant to propose such a term because it might also signal to the employer that the potential employees are litigious. ${ }^{114}$ But by adopting the mark, the employer can satisfy employee demand (at low cost) without requiring this kind of signaling.

112. Ian Ayres \& Richard F. Ober, Jr., Corporate Non-Discrimination Policies: The Hollow Promise 3-4 (2006) (unpublished manuscript, on file with author).

113. Id. at 4 .

114. It is a well-known result of contracting theory that defaults will become sticky when suggestions to alter the contract reflect badly on the proposer. Omri Ben-Shahar \& John Pottow, On the Stickiness of Default Rules, 33 FLA. ST. U. L. REv. (forthcoming 2006), available at http://www.law.umich.edu/centersandprograms/olin/abstracts/discussionpapers/2005/ 05-010benshahar.pdf; Ian Ayres \& Robert Gertner, Strategic Contractual Inefficiency and the Optimal Choice of Legal Rules, 101 YaLE L.J. 729 (1992); Jason Scott Johnston, Strategic Bargaining and the Economic Theory of Contract Default Rules, 100 YALE L.J. 615 (1990). 
Of course, one needs to consider whether adopting the mark would make other employees less likely to work for the employer. At least as a theoretical matter, adoption could induce employee boycotts. While worthy of consideration, we doubt that this is a serious concern. At least with regard to employers that have voluntarily included sexual orientation in their nondiscrimination policies, it is unlikely that there would be any additional adverse impact of adopting a formal commitment not to discriminate. And more generally, the public opinion is strongly in favor of equal employment opportunity. It is hard to imagine many applicants saying, "I refuse to work for Company $\mathrm{X}$ because it promises not to discriminate."

An employer's adoption of the mark might also be driven by employee preferences in another way. Unions might collectively bargain for adoption of the mark. Pride at Work, the AFL-CIO affiliate group that promotes LGBT employment equality, has already been successful in having formal nondiscrimination promises included in union contracts. ${ }^{115}$ But unions usually bargain for enforcement procedures that utilize union grievance procedures-and unions may be reluctant to bargain for adoption of the mark because it allows individual union members independent private rights of action. ${ }^{116}$

Adopting the mark might also facilitate the flow of other inputs, including the certification of oversight organizations. Certifying organizations may urge or require adoption of a binding commitment not to discriminate. The Association of American Law Schools (AALS), for example, not only requires member schools to include sexual orientation in their own nondiscrimination policies, but also to stop discrimination by employers utilizing the schools' career placement facilities. ${ }^{117}$ But neither of these provisions requires a legally binding promise not to discriminate. For example, AALS provides as follows:

A member school shall inform employers of its obligation under Executive Committee Regulation 6-3(b) [the AALS's nondiscrimination policy], and shall require employers, as a condition of obtaining any form of placement assistance or use of the school's facilities, to provide an assurance of the employer's willingness to observe the principles of equal opportunity stated in Bylaw 6-3(b). ${ }^{118}$

115. For a guide to negotiating such contracts, see Pride At Work, Seven Easy Steps For Adding Domestic Partner Benefits To Your Union Contract (Apr. 2005), http://prideatwork.org/ public/documents/press/2005/Seven\%20Easy\%20Steps\%20For\%20Adding\%20Domestic\%20Partner $\% 20$ Benefits\%20To\%20Your\%20Union\%20Contract.pdf.

116. Indeed, it is arguable that an employer's signing of the licensing agreement in any unionized setting might constitute a violation of its collective bargain duty. But no union to our knowledge has ever complained about inclusion of sexual orientation in nondiscrimination policies which, at least probabilistically, also create independent rights of action.

117. Association of American Law Schools, 2005 Handbook 60 (2005).

118. Id. AALS Bylaw 6-3(b) provides as follows:

A member school shall pursue a policy of providing its students and graduates with equal opportunity to obtain employment, without discrimination or segregation on the ground of race, color, religion, national origin, sex, age, disability, or sexual orientation. A member school 
Providing "an assurance" of a "willingness to observe the principles of equal opportunity" may well fall short of a promise not to discriminate. Indeed, many law schools fail to require a clear promise. For example, for years Yale Law School has merely required employers participating in the school's interview programs to sign the following "Non-Discrimination Statement":

I, [Name of Representative] an authorized representative of [Name of Employer] affirm that said employer is aware of and complies with Yale Law School's nondiscrimination policy, as stated below:

Yale Law School reaffirms its policy against discriminatory employment practices. The law school does not countenance any form of discrimination based upon age, color, handicap or disability, ethnic or national origin, race, religion, religious creed, gender (including discrimination taking the form of sexual harassment), marital, parental or veteran status, sexual orientation, or the prejudice of clients. ${ }^{1}$

The legal effect of this document is not free from doubt. The representative is signing a "statement," not a "contract." She is "affirming," not "promising." The key question is whether "affirm[ing] that said employer ... complies with" the law school policy of "not countenanc[ing] any form of discrimination based upon ... sexual orientation" is a legally binding contractual commitment. And if it is, it is uncertain whether students have third-party beneficiary status to enforce violations of the promise.

But just as the Corporate Equality Index could be easily changed to require binding legal commitments, the AALS provisions and the law school "Non-Discrimination Statement" could be easily changed to require promises. AALS Bylaw 6.4(b) could be amended in this manner:

A member school shall torequire each employer to whom it furnishes assistance and facilities for interviewing and other placement functions the promise to observe the principle of equal opportunity.

Alternatively, the AALS might simply require that member schools (1) sign the Fair Employment license, and (2) require employers receiving placement assistance to sign the license. ${ }^{120}$ Such a requirement-by a power-

shall communicate to each employer to whom it furnishes assistance and facilities for interviewing and other placement functions the school's firm expectation that the employer will observe the principle of equal opportunity.

Id.

119. Yale Law School Career Development Office, Registration Form for Fall Interview Program 2005, http://www.law.yale.edu/outside/pdf/Career_Development/cdo-empreg05.pdf (last visited Jan. 26 2006).

120. A third and analogous regulation would be a requirement that member schools promise not to discriminate on the basis of sexual orientation in their own admissions. AALS Bylaw 6-3(a) currently requires that member schools "shall provide equality of opportunity . . . without discrimination ... on the ground of ... sexual orientation." But member schools need to provide applicants with a viable private cause of action-and few schools clearly do. Association of AMERICAN LAW ScHOOLs, supra note 117 , at 33-34. 
ful input supplier-would in one fell swoop provide clear and enforceable private causes of action to the direct victims of employment discrimination.

The restrictions on employer recruiting are animated by law schools' desire not to have their facilities used in the service of discrimination. A similar motivation might apply to faculty recommendations. Many faculty would not want to participate in the evaluation process for an employer that retains the legal right to discriminate on the basis of sexual orientation. The Fair Employment mark gives faculty a means to make sure they steer clear of such employers. In the not-too-distant future, one could imagine that faculty might decline to write recommendations to employers that refused to sign the license.

Beyond these requirements, input suppliers can powerfully influence the contracting equilibrium just by the way they frame questions. Consider for example NALP, the National Association for Law Placement. Its law firm questionnaire currently makes the open-ended request: "State your organization's nondiscrimination policy." ${ }^{, 12}$ But imagine what would happen if instead it asked, "Has your organization promised not to discriminate on the basis of sexual orientation?" We predict that the vast majority of firms would check "Yes" and in so doing would probably give applicants an enforceable legal right to sue for violations of the promise. ${ }^{122}$ Or alternatively, NALP could more directly exploit the subject of this Article by asking, "Has your organization licensed the Fair Employment mark?"

At the end of the day, adoption of the license is not just a recruitment tool, but for many employers it might be a way of staying in good graces with a variety of input suppliers-including certifying and membership organizations and outside evaluators. Both the push of institutional pressure (as already seen in the case of union and AALS requirements) and the pull of recruiting advantages (as seen in NALP disclosures of nondiscrimination policies) may tip employers toward adoption.

\section{Additional Consumer Demand}

While upstream input suppliers may motivate some employers, the prospect of additional downstream demand as a motive for adoption is more directly tied to the idea of a certification mark. The Fair Employment mark certifies nondiscrimination to potential employees, but like other certification marks, the Fair Employment mark can also be used as a marketing tool to certify product quality to potential purchasers. In this Section, we will explore the plausible impact of the mark on consumer demand-first, in a world of "acoustic separation" (where sellers are able to convey a targeted message to gay rights supporters without signaling opponents) and second,

121. National Association of Legal Professionals, Law Firm Questionnaire 2005-2006 Academic Year, http://www.law2.byu.edu/Career_Services/firmform.pdf (last visited Feb. 23, 2006).

122. An applicant who had been discriminated against could not only argue that he or she was an intended third-party beneficiary of the promise, but could also argue that, by checking the box on the NALP recruitment form, the organization was offering not to discriminate in return for the applicant's application. 
in a world of full information where the prospect of consumer boycotts must be weighed against the benefits of consumer "buycotts."

\section{Government Contractor Ordinances}

Before delving into these questions of impact on generalized consumer demand, it is important to appreciate the possible impact of what we might call "regulated demand." Just as the last Section illustrated the potential impact of input pressure that has been brought to bear by particular unions and certifying organizations, demand-side pressure can be brought to bear by particularly powerful individual purchasers - state and local governments.

Dozens of cities and counties prohibit public contractors from discriminating on the basis of sexual orientation. ${ }^{123}$ These government entities in effect will only purchase goods and services from suppliers that promise not to discriminate. These contractor ordinances are at times redundant with state statutory prohibitions on employment discrimination. Thus, for example, San Jose's ordinance prohibiting discrimination by city contractors does not substantively affect any California suppliers, who are independently prohibited from sexual orientation discrimination by state statute. ${ }^{124}$ But these contractor laws have potential bite in two different circumstances. First, they have sometimes been adopted by cities and counties located in jurisdictions that have not prohibited private employment discrimination on the basis of sexual orientation. For example, Phoenix and Cleveland require nondiscrimination by city contractors, but their respective states do not prohibit discrimination by employers generally. ${ }^{125}$ Second, even in places (such as San Jose) where employment discrimination by private employers is generally prohibited, the local ordinances can still have an impact as local governments sometimes contract with out-of-state suppliers that would otherwise be allowed to discriminate.

But to date, local compliance officers have lacked an effective mechanism for assuring compliance. Much like the AALS and its member schools, the compliance officers have been satisfied with contractor assurances that they do not discriminate or the contractors' inclusion of sexual orientation in their nondiscrimination policies. But as explained above, these nondiscrimination policies are at times nonbinding commitments, often failing to equip the victims of discrimination with effective enforcement mechanisms. The advent of the Fair Employment mark changes all this. Compliance officers can simply ask whether a contractor has signed the license. As we move forward to roll out the mark, we plan to urge local contractor compliance

123. See generally Wayne van der Meide, The Policy Inst. of the Nat'l Gay and Lesbian Task Force, Legislating Equality: a Review of laws affecting Gay, Lesbian, Bisexual, and Transgendered People in the United States (2000), http:// www.thetaskforce.org/downloads/legeq99.pdf.

124. Id.

125. See generally Phoenix, Ariz., Code § 18-15 (2005); Cleveland, Ohio, Admin. Code $\S 187.04$ (1994); Cleveland, OHIo, OfFenses \& Bus. ACtivities Code $§ 667.05$ (1997); see also Town of Lake Park, Fla., Code § 2-110 (1996). 
officers to consider promoting or requiring the use of the mark as a means of fulfilling the cities' requirements. At the very least, the mark should provide a credible commitment device for contractors that are trying to demonstrate their compliance with a city's nondiscrimination mandate.

\section{The Impact on Demand in a World of "Acoustic Separation"}

An employer may worry that adopting the mark will promote a backlash of reduced demand. The very hostility toward gay, lesbian, and bisexual people that makes the protections of the mark valuable could also work against the mark. Opponents of gay rights can read product labels as well as allies, and some companies may refuse to use the mark out of fear of boycotts. But before considering the impact of boycotts, we first explore how the mark might work in a world with a kind of "acoustic separation"-that is, a world in which the proponents of gay rights learn of a firm's adoption, but the opponents of equality do not. ${ }^{126}$

The benchmark of "acoustic separation" is not as outlandish as it might first appear. The kosher symbol provides one possible illustration. The " $U$ " encircled by an "O" is so innocuous that many anti-Semites miss the signal, even though they might wish to punish companies that affirmatively market products to Jewish consumers. ${ }^{127}$ The Fair Employment mark proposed here would be similarly opaque. For consumers "in the know," the mark could create incentives to buy particular products. But there is nothing about the appearance of the mark as proposed to tie it to gay rights or gay people generally. More explicitly "gay" symbols-a pink triangle, a rainbow flag, or the Greek letter lambda-would certainly be more transparent: even consumers who had never heard of the mark would know that the company using the symbol is positioning itself in sympathy with the gay community. But this more explicit positioning would also run the risk of alienating consumers who are hostile to gay rights (who will react to an explicitly "gay" symbol but not to a neutral one).

Moreover, an employer's adoption of the license gives the employer the option, but not the duty, to display the mark. The mark need not be displayed on every product or indeed on any product. Licensees may choose to display the mark selectively, in contexts where it is more likely that allies will see the mark. They might decide to display the mark only in certain advertisements or in certain states.

By reaching out to ally consumers, the Fair Employment mark promotes a kind of "buycott." It allows equal rights proponents to "vote with their wallets." The time may be particularly ripe to troll for pent up equality de-

126. See Meir Dan-Cohen, Decision Rules and Conduct Rules: On Acoustic Separation in Criminal Law, 97 HaRv. L. Rev. 625 (1984).

127. Occasionally, anti-Semitic groups do call for boycotts of products labeled as kosher, but these movements seem to attract few followers. See, e.g., Anti-Defamation League, Bigotry Over a Beer Label, http://www.adl.org/special_reports/kosher_tax/kosher_coors.asp (last visited Jan. 23, 2006) (noting that some extremist groups call for a boycott of foods and companies that succumb to the "kosher conspiracy"). 
mand. Progressives who are trapped in "red" states do not have a governmental outlet for their political perspective to be heard. Patronizing firms that have privately adopted ENDA-have promised not to discriminate-is a pragmatic way of making progress on employment equality, particularly when local and federal legislatures are not ready to act.

Even opponents of marriage for same-sex couples could be counted as potential consumers of products bearing the mark. A frequent claim of marriage opponents is that they believe in treating gay people fairly, but they just think that marriage by definition is between a man and a woman. By embracing the Fair Employment mark either as licensees or consumers, marriage opponents can prove their bona fides as believers in employment equality.

In recent years, gay rights advocates have sometimes flexed the community's economic muscles. The "gay dollar" is now a recognized-if controversial-phenomenon. By stamping or writing the words "gay dollar" on ordinary dollar bills, the gay community can tangibly signal the number of dollars that literally pass through gay hands. These marked dollars are meant to demonstrate the spending power of the gay community. The gay community and its supporters have sought to exercise that spending power positively. For example, when voters in Tampa, Florida, enacted an antigay rights ordinance, the Human Rights Task Force of Florida responded by instituting a buycott rather than a boycott. The group published a directory of businesses that have "policies in support of gays and lesbians." ${ }^{128}$ In the first five months of the directory's publication, the list grew from 105 to 430 entries. ${ }^{129}$ Todd Simmons, spokesperson for the Human Rights Task Force of Florida, explained, "We decided on an approach that would empower us economically and politically. The buycott has improved our standing in the community. Businesses and other institutions have changed their policies to get in our book." 130

Large companies have launched advertising campaigns targeted to gay consumers, including AT\&T, Anheuser-Busch, Apple Computer, Benetton, Philip Morris, Seagram, Sony, and Absolut. ${ }^{131}$ George Slowik, publisher of Out magazine, notes that gay men and lesbians are "an audience not accustomed to being courted, so they're more apt to notice who's supportive and who's not, particularly at this point. The first ones in will reap extra benefits

128. Michael Wright, Avoidance Tactics, AtLantic Monthly, Oct. 1993, at 44, 48.

129. Id.

130. Id.

131. Stuart Elliott, A Sharper View of Gay Consumers, N.Y. Times, June 9, 1994, at D1. The story of Absolut vodka illustrates the way gay and lesbian consumers demonstrate loyalty to supportive manufacturers and other businesses. Absolut, it seems, was one of the first major labels to advertise in gay publications. According to Rick Dean, Vice President of Overlooked Opinions, "The gay community tied it back-Absolut was there on the back cover of gay publications before the others, and Absolut vodka is poured at gay bars." Mary Gottschalk, Gay Cachet: Advertisers Get Wise to the Fact that the Gay and Lesbian Community Is a $\$ 500$ Billion a Year Gold Mine, SAN Jose Mercury News, Sept. 19, 1993, at 1 H. 
in each category."132 The same sort of loyalty that allows a firm to "reap extra benefits" as the "first one in" could allow the first firms that adopt the mark to reap extra revenue from consumers wishing to show their support for nondiscrimination. ${ }^{133}$

M.V. Lee Badgett has examined the three distinct roles that gay, lesbian, and bisexual people can play in an economic system: "consumers," "investors," and "producers." 134 Many companies have recognized the LGBT community as an important group of consumers and have developed advertising to target this market. The concerns of gay people and their allies as investors are reflected in rating systems that grade companies for their gayfriendliness. ${ }^{135}$ As producers, LGBT people get some recognition in nondiscrimination policies, statutes, and local ordinances; employee benefit programs; and other incentives offered by companies that wish to recruit talented people, regardless of sexual orientation. Tools like the HRC Corporate Equality Index can help potential employees to identify the companies that respect LGBT people as producers. The Fair Employment mark complements these existing strategies as it conveys information about companies' employment practices to a wider audience in a decentralized way. In a sense, the mark completes the circle by allowing gay and nongay consumers to tie their purchasing decisions to the fair treatment of gay and lesbian employees.

A key characteristic of the mark is that it could facilitate heterosexual support for gay rights in ways that need not be public. This could create opportunities to work for gay rights for a new group of "stealth" supporterspeople who, for any number of reasons, are not able or willing to act publicly, but who wish at the very least to spend their money responsibly. As heterosexual consumers begin to feel aligned with the cause through their purchasing decisions, other more public forms of support might start to feel comfortable as well. Perhaps most importantly, from simple, every day consumer choices, an internal sense of connection to and identification with LGBT people could grow. This internal change might lead nongay people to act-especially to speak up for equality in various contexts. Thus, a small

132. Id.

133. This brand loyalty is also evident in the travel industry. According to one marketing executive, "All a mainstream company has to do is show up at a gay travel expo and because of brand loyalty, gay and gay-friendly travelers will use them and their business will increase." Stu Glauberman, Gay Tourism: Island Companies Tap a Growing Market, Honolulu Advertiser, Feb. 14, 1994, at Cl.

134. M.V. Lee Badgett, Thinking Homo/Economically, in Overcoming HeTerosexism AND Homophobia: StRategies that Work 380 (James T. Sears \& Walter L. Williams eds., 1997).

135. The Equality Project, for example, "is a consumer, employee and investor advocacy coalition working to support and monitor workplace awareness and adoption of the progressive policies expressed in the Equality Principles as endorsed by leading LGBT organizations." The Equality Project, http://www.equalityproject.org/content/accomp.html (last visited Jan. 29, 2006). The HRC Corporate Equality Index also helps investors avoid discriminatory companies and direct their money to companies that treat LGBT employees fairly. Human Rights Campaign Foundation, supra note 68 . 
symbol on a product label could help to mobilize a broader base of heterosexual support for LGBT equality.

\section{The Impact on Demand: Boycotts}

Notwithstanding the innocuous nature of the mark itself and notwithstanding the selective and targeted disclosure of the mark by licensees, it is still possible that adopting the mark will cause a licensee to lose some potential consumers of its goods or services. Adopting the mark may cause a conservative group to call for boycotts of the gay-friendly company. Even more troublesome, licensees must consider whether adoption will cause individual consumers independently to shift their consumption to other suppliers. Consumers may be turned off by the politicization of the product. The privacy of the grocery aisle, which liberates allies to purchase the product without being challenged, also may liberate opponents to buy a close substitute without being challenged. Indeed, the decision to switch might not even be based on conscious disapproval of the firm's adoption of the mark; it might be an unconscious or implicit attitude. ${ }^{136}$ While boycotts are seldom effective, ${ }^{137}$ the fear of individual, unconscious turnoffs should not be ignored by any profit-maximizing producer.

The concern that the mark may disaffect some consumers may be particularly important for firms with large market shares. In concentrated industries where a few companies have captured the market, each company has a lot to lose if it alienates a significant portion of the market. In such markets, a boycott could cause real economic loss if antigay consumers far outnumber pro-gay consumers. In such circumstances, it will always be in at least one company's self-interest to reject the mark-being known as the one company that is not "gay friendly" could help that company capture antigay consumers' business (just as the Fair Employment mark would help companies capture the business of pro-gay consumers).

But in markets with many firms, the story is very different. Even in a world where opponents of employment equality substantially outnumber equality advocates, there will be robust incentives for a few of the firms to adopt the mark. To see how this works, let's imagine a stylized market consisting of ten hammer makers. Suppose that hammers are so uniform that consumers are completely indifferent about the source of hammers they buy; consumers purchase randomly, so each manufacturer gets $10 \%$ of the market. Suppose further that $5 \%$ of customers support equal employment rights for gay men and lesbians so strongly that they will go out of their way to buy hammers from the company that treats gay employees fairly. ${ }^{138} \mathrm{We}$ are

136. See generally Anthony G. Greenwald \& Mahzarin R. Banaji, Implicit Social Cognition: Attitudes, Self-Esteem, and Stereotypes 102 PsYCHOL. REv. 4 (1995).

137. Brown, supra note 95, at 812 .

138. On one hand, this seems to be an extremely conservative assumption, since eighty-eight percent of Americans oppose employment discrimination on the basis of sexual orientation, according to a 2003 Gallup Poll. George GalluP, JR., supra note 1, at 160, 162; see also L.A. TimeS 
not assuming that $5 \%$ would cut off their arm to further gay rights, but other things being equal (such as price), they would strongly prefer sellers that promised not to discriminate. But imagine that four times as many consumers-20\%-actively dislike or disapprove of gays (enough that they will avoid purchasing from companies that treat gay employees fairly). The remaining $75 \%$ of the consumers do not care one way or the other.

Now consider what happens to the first company adopting the Fair Employment mark. Even if that company loses all of its business from the antigay consumers, that difference is more than made up by the pro-gay consumers who are induced to buy products bearing the mark. The first mover increases from a market share of $10 \%$ (before using the mark) to a 12.5\% market share after adopting the Fair Employment mark. This increase in demand results despite the fact that the company loses its share of the antigay customers' business. The company is still getting its random tenth of the consumers who don't care (one-tenth of $75 \%=7.5 \%$ ), plus all of the consumers who support gay rights $(5 \%)$.

How can this be-that a firm has an incentive to adopt the mark when consumers who dislike the mark outnumber those who like it four to one? The answer is that most of the opponents were not going to buy from the first-adopter firm anyway. Because there were ten identical firms in the market, the first adopter only had a $10 \%$ chance of getting any consumer to buy. From the first-adopter's perspectives, the antigay consumers fall from a $10 \%$ chance to a $0 \%$ chance of buying. But the pro-gay consumers rise from a $10 \%$ chance to a $100 \%$ chance of buying. Because of this disproportionate change in shifting probabilities, the buycott effect is likely to be much stronger than the boycott effect for first-adopters in markets with many firms. Of course, in the real world the pro-gay consumers will not go all the way to $100 \%$ probability of buying - but the underlying idea that firstadopters will not be deterred, even in the face of considerable antigay consumer sentiment, still holds true.

Indeed, in our stylized example, a second firm will have an incentive to use the mark as well. The two "marked" firms will now split the pro-gay consumers, so each gets $10 \%$ of the market $-7.5 \%$ (one-tenth of consumers who do not care) plus $2.5 \%$ (half the pro-gay consumers). ${ }^{139}$ In equilibrium, all the firms will have the same $10 \%$ market shares that they began with. An economist at Columbia piped up at a presentation of this paper and was heard to say, "So the mark didn't make any difference." How wrong he was! Even though market shares settle back to their pre-mark status, employment protections for $20 \%$ of gay and lesbian employees in the industry have improved.

This example suggests that the Fair Employment mark could create some very strong "first mover" advantages-if only to capture the gay-

PoLl, supra note 1. On the other hand, this group of Americans might not feel so strongly about the issue that they would make purchasing decisions based on it.

139. Some of the remaining eight firms may affirmatively signal their antipathy for gays to gain some of the antigay consumers. 
supportive consumers who remain brand-loyal even after other brands adopt the mark. ${ }^{140}$ In a generalized version of this example, we would expect at least one adopter as long as there are at least five firms. ${ }^{141}$ But there is also a very strong incentive for another company to become the "second mover."

If we more realistically assume that the distribution of the pre-mark market share is not random, we still see that producers with small market shares will have incentives to adopt the mark. Assume a ten-company industry in which five companies have $15 \%$ market shares and five companies have 5\% market shares. If one of the smaller-share companies were to adopt the mark, it would stand to move from a $5 \%$ share to an $8.75 \%$ share-all of the pro-gay consumers $(5 \%)$ plus one-twentieth of the neutral consumers $(3.75 \%)$. This is a sizable jump, one that would raise the company's sales by $75 \%$. As long as one firm in the industry has less than a $20 \%$ market share, there will be at least one firm with an economic incentive to adopt the license. Additional firms will adopt as long as the resulting market share of the adopters is less than or equal to $20 \% .^{142}$ In this asymmetric market share example, in equilibrium, four firms that start with $5 \%$ market shares will have incentives to adopt the mark.

This example shows that the potential benefits of using the Fair Employment mark could outweigh the potential costs, at least for a few companies. But we should emphasize that the assumed four-to-one ratio of antigay to pro-gay consumers is wildly at odds with the public attitude toward equal employment rights. In a world where $88 \%$ of Gallup respondents say it is wrong to discriminate in employment on the basis of sexual orientation, it is inconceivable that $20 \%$ of consumers would actively shun a product that promised not to discriminate. Instead, the point of the exercise is to emphasize that the threat of demand reduction does not pose an impediment to adoption of the mark by part of an industry. Just as smallness is a spur to Delaware's innovation in corporate federalism, ${ }^{143}$ theory suggests that fringe firms with smaller market shares should lead the way with the Fair Employment mark.

\section{E. Corporate Morality}

Firms that have already publicly embraced nondiscrimination on the basis of sexual orientation are likely adopters of the Fair Employment license. Organizations that identify with a commitment to the cause of equality may

140. The first mover also has a better chance of selling the product to antigay consumers before they catch on to the meaning of the mark, but we hesitate to give much weight to this sneaky motivation.

141. If $\mathbf{P}=$ proportion of pro-gay consumers, $\mathrm{A}=$ proportion of antigay consumers, and $\mathrm{N}=$ number of firms, then it can be shown that at least one firm will adopt the license so long as (N-1)P $>A$. The largest integer smaller than $N^{*} \mathrm{P} / \mathrm{A}$ defines the number of firms that will adopt.

142. More generally (using the notation of the previous footnote), firms will continue to adopt as long as the total market share of adopting firms is below $\mathrm{P} /(\mathrm{P}+\mathrm{A})$.

143. Brown, supra note 95, at 819; Roberta Romano, Law as a Product: Some Pieces of the Incorporation Puzzle, 1 J.L. ECON. \& ORG. 225, 225-27 (1985). 
adopt the mark not because of the foregoing recruiting or marketing benefits, but merely because licensing is consistent with the organization's selfconception.

While it is natural to think of employers as corporations with a singleminded profit motive, there are many nonprofit employers that by definition pursue other goals. For example, universities are nonprofits that employ substantial numbers of people. It should be no surprise from an organizational-identity perspective that these academic nonprofits have taken a lead in including sexual orientation in their nondiscrimination policies. Employers that have included sexual orientation in their nondiscrimination policies are therefore natural candidates for adoption of the Fair Employment mark.

A subset of these employers that have already adopted nondiscrimination policies are especially likely to adopt the mark. The Human Rights Campaign has been successful in convincing over a hundred corporations to endorse the passage of ENDA. ${ }^{144}$ These corporations that have said they want to be bound by the substantive duties of ENDA would be hard-pressed not to adopt a license imposing these same duties.

Of course, a corporation might argue that it would only be willing to take on these duties if its competitors had to as well. After all, it is not unreasonable to support a fifty-cent gasoline tax if borne by all, but protest if asked to pay it individually. Given our earlier empiricism on claiming rates under state nondiscrimination statutes, it is unlikely that fear of competitive cost disadvantage would chill an endorser's willingness to adopt the license. But the cost of potential boycotts might scare a firm with large market share from becoming a first mover. Such a firm would probably prefer that the nondiscrimination norm become mandatory to forestall loss of customers.

We believe there are strong reasons to expect a predictable subset of employers to sign the licensing agreement. The identifiable employers would be those who (1) have relatively small market shares; (2) have already included sexual orientation in their nondiscrimination policies or publicly endorsed ENDA; (3) supply cities that require public contractors not to discriminate; (4) are members of certifying organizations that prohibit discrimination; or (5) are located in jurisdictions that independently prohibit sexual orientation discrimination.

Of course, some employers might believe that the benefits of signing outweigh its costs, but still resist because they fear "slippery slopes." If they make this promise, they might worry that a never-ending parade of other

144. The list includes a variety of blue-chip stocks and household names: Agilent Technologies Inc., Apple Computer Inc., AT\&T, Bausch \& Lomb, Ben \& Jerry's Homemade Ice Cream, Borland International, BP, Capital One Financial Corp., Charles Schwab \& Co. Inc., Chubb Corp., Cisco Systems, Coors Brewing Co., Corning Inc., Digi-Net Syndication, Eastman Kodak, Electronic Arts, FleetBoston Financial Corp., Trillium Asset Management, General Mills, Hewlett-Packard Co., Hill and Knowlton, Honeywell, IBM, Imation, Intel Corp., JP Morgan Chase \& Co., John Hancock Financial Services Inc., Kaiser Permanente, Levi Strauss \& Co., Louis Dreyfus Corp., MFS Investment Management, Microsoft, Millipore Corp., Nationwide, Nike Inc., Oracle Corp., Prudential Insurance Co., Quark, SGI, Shell Oil Co., Software Spectrum Inc., State Street Corp., The Quaker Oats Company, Triarc Beverage Group, Verizon Communications, Wainwright Bank, Worldspan L.P., Xerox, Yahoo Inc. Human Rights Campaign Foundation, supra note 45. 
certification promises will follow, with pressure applied to sign each one. This argument, like others, will have different salience for different employers. The same slippery slope argument could be used to resist including additional categories in a firm's nondiscrimination policy: if an employer includes sexual orientation, it will then be pressured to include gender identity (or attractiveness, or weight). But employers that have been willing to take on this slippery slope risk in including sexual orientation in their nondiscrimination policies are more likely to be willing to take on some additional slippery slope risk with regard to legal commitments not to discriminate.

\section{RESPONDING TO CRITICISMS}

The last Part was concerned with whether too few employers would sign the licensing agreement. Here we ask the converse question: will too many employers sign? Specifically, this Part takes on four different criticisms concerning privatization of civil rights duties. Could it be that giving employers a convenient mechanism to promise not to discriminate somehow hurts the cause of employment equality?

\section{A. Reducing Demand for a Statutory Prohibition}

As an initial matter, we should consider whether the Fair Employment mark might take the wind out of the sails of the push for passage of ENDA itself. We have argued for the mark as an incremental strategy that could be used as a step in the process of compelling all employers not to discriminate on the basis of sexual orientation. But a pervasive concern with incrementalism is the possibility that it will cause a movement to stall out short of its ultimate goal. The privatization of ENDA duties might work as a substitute, rather than a complement, to national passage of legislation protecting lesbian and gay people in employment.

This concern recently drove the leading marriage equality group in Connecticut, Loves Makes a Family, to oppose a civil-union bill for same-sex couples. Although the civil-union bill would immediately grant same-sex couples all of the legal rights of marriage (and represent the first time that a state legislature free from court order had conferred full benefits), ${ }^{145}$ the group worried that legalizing civil unions would take the "wind out of the sails" of the equal marriage rights movement. ${ }^{146}$ The group's executive director, Anne Stanback, told the joint judiciary committee of the General

145. California has come close with domestic partnership, however.

146. Daniela Altimari, Lawmakers Favor Civil Unions, Despite Objections, HARTFORD Courant, Feb. 8, 2005, at B1 ("Stanback said that she would rather the legislature do nothing than approve civil unions, which she said aren't a 'stepping stone' on the road to gay marriage but a stopping point in the debate. Since Vermont enacted civil unions, its legislature now has no interest in revisiting gay marriage, she said."). 
Assembly that she feared a civil-union bill would not be a stepping stone to marriage but a stopping point. ${ }^{147}$

As a theoretical matter, we might be agnostic about whether voluntary adoption by a portion of employers would increase or decrease demand for a mandatory ENDA-like statute. We might expect a snowball effect as momentum grows behind employment protections for gay and lesbian people. But from a public-choice perspective, if adoption of the mark satisfied the demands of the most ardent proponents of nondiscrimination, the Fair Employment mark could reduce the pressure for a federal statute. City and state laws prohibiting discrimination could have a similar impact. Charles Shipan and Craig Volden have empirically measured these competing snowballversus-pressure valve effects with regard to the diffusion of city antismoking laws. ${ }^{148}$ In this context, they concluded that the "snowball effect" dominated-states were more likely to pass antismoking legislation if cities had already enacted similar legislation.

We think a snowball effect is likely to dominate here as well. The thirst of gay rights proponents will not be quenched by partial, voluntary adoption. We imagine that employers will adopt the mark as a beacon to other like-minded employers. Ultimately, the covered entities will want their competitors to be covered as well. This is especially true once there is sufficient entry into the market to dilute away the initial advantage of first-mover licensees.

In our stylized market of ten hammer manufacturers, the first adopter increased its market share. This sole adopter would not benefit from the passage of ENDA. But in that example, the adoption of the mark by a second firm absorbed the economic advantage and returned all ten firms to their ex ante market shares. It is at this point that adopters as well as non-adopters would welcome the legislation that "forces" them to do what they would want to do anyway - hire the most qualified individual. Moreover, the demonstration benefits of the mark that we described above are benefits that lower the cost of enacting. Public support for the law, low litigation rates, and some record of how courts interpret the statutory language are elements that could enhance the "snowball" impact of the law.

When push comes to shove, it is difficult to turn down the immediate "bird in the hand" benefits of incremental progress. Indeed, returning to the Connecticut civil-union debate, it should not surprise us that Love Makes a Family ultimately softened its stance on civil unions. When a civil-union bill was eventually voted out of committee, the group chose not to oppose it-

147. Id. Stanback initially testified that, if a civil union bill was brought up for a vote, Love Makes a Family (LMF) would lobby for its defeat. LMF subsequently withdrew this threat when members decided that defeat of the civil union bill would do more harm than good, and Anne Stanback declared it a "great day" when Connecticut Governor Jodi Rell signed the civil union bill into law. Gregory B. Hladky, Rell Signs Civil Union Legislation into Law, New Haven Register, Apr. 21,2005 , at A1.

148. Charles R. Shipan \& Craig Volden, Policy Diffusion from Cities to States: Antismoking Laws in the U.S. (Jan. 31, 2005) (unpublished manuscript), available at http://www.law.yale.edu/ leo/papers/shipan.pdf. 
even as it continued to press for marriage equality. It is similarly difficult to oppose an effort to give gay and lesbian employees an enforceable nondiscrimination promise-even if federal legislation is the ultimate goal.

\section{B. Contingent Demand for a Statutory Prohibition}

A related concern is that the mark might promote a kind of conditional demand for statutory prohibitions. Think of this as the dark side of the demonstration benefit. The experience of the licensees provides legislatures with valuable information. But what happens if this information is bad news? What happens if we find that (1) few employers adopt the mark; (2) there is an unexpectedly large amount of litigation (leading chastened employers to terminate their licenses); or (3) "activist" judges and juries ${ }^{149}$ radically expand the contours of liability (also leading chastened employers to terminate their licenses)?

The demonstration effects of the mark could make legislators' support for civil rights empirically contingent. The norm of nondiscrimination becomes a hostage to fortune. Some might argue that it is wrong to hitch our wagon to such an uncertain star.

We disagree. This is a situation where more information is a good thing. ${ }^{150}$ Let's consider the list in reverse order. If judges are misconstruing the intended duties of ENDA, it is appropriate for legislators to take these precedents into account in redrafting the statute. If the mark leads to unexpectedly high litigation rates, Congress (and society) might learn that there is more disparate treatment on the basis of sexual orientation than we had earlier perceived. However, if the litigation spike is caused by frivolous or unsubstantiated claims (reflected in high rates of summary judgment or dismissal for failure to state a claim), we think it is again appropriate for legislators to consider these effects in deciding whether to redraft the statute. Finally, we believe that even if firms fail to adopt the mark, this does not necessarily send a dire negative signal. The mark is a sufficiently novel idea that lack of adoption can be explained away by a number of neutral reasons, including (misguided) narrow self-interest.

And if history is any indication, the news about the mark will not be bad. One of the most startling things about some gay rights victories is how

149. In 1991, Congress amended Title VII to create the right to trial by jury and to entitle plaintiffs to recover compensatory and punitive damages, within certain caps based on the size of the employer. See Civil Rights Act of 1991, 42 U.S.C. $\$ 1981$ a(c)(1) (2000). Just as Title VII cases can be tried to a jury, so too ENDA claims seeking compensatory or punitive damages would almost surely be subject to jury trial. Section 12(b) of ENDA makes "the procedures and remedies applicable to a claim alleged by an individual for a violation of this Act" the same as "the procedures and remedies applicable for a violation of title VII of the Civil Rights Act of 1964 (42 U.S.C. 2000e et seq.)." S. 1705, 108th Cong. \$ 12(b) (2003). As is true in civil cases generally, the jury trial may be waived if no demand is made for a jury or if a demand has been made but all parties subsequently agree to waiver. See FED. R. Crv. P. 38(d); id. 39(a)(1).

150. But see Jennifer Gerarda Brown \& Ian Ayres, Economic Rationales for Mediation, 80 VA. L. Rev. 323 (1994); Ian Ayres \& Barry Nalebuff, Common Knowledge as a Barrier to Negotiation, 44 UCla L. Rev. 1631 (1997); and Bruce Ackerman \& Ian Ayres, Voting with Dollars (2002), for circumstances in which non-transparency can promote social welfare. 
little they change the world for most people. Marriage was extended to same-sex couples in Massachusetts (as well as some Western European countries) and the sky did not fall. Openly gay and lesbian service members were welcomed into the armed forces of the European Union and we see business as usual (even when those forces cooperate with their American colleagues). The experience of the seventeen jurisdictions that already prohibit private employment discrimination shows us that adoption of the mark is not likely to open a Pandora's box of litigation or unwarranted claims. This is a bet that proponents of gay rights should be willing to make.

\section{Commodifying Equality}

A third concern about the mark is that it could cause the concept of equality to slip from being an inalienable right to a commodity which employers guarantee only if the cost is low. Our earlier economic appeals for adoption might offend some who believe that right-minded employers should support nondiscrimination simply because it is a basic human right. To commodify the value of equality is to suggest an invidious economic calculus.

To these concerns, we plead guilty. And we confess: we are commodifiers. But we are also pragmatists. We have the strong sense that nondiscrimination in employment is consistent with robust capitalism. Once people see that employment equality does not undermine profitability, it will be very hard to take away. To our minds, securing this basic right a few years earlier is worth the psychological cost of commodification.

In many ways, the ship of commodification has already sailed. When HRC tries to convince employers to endorse ENDA or adopt the HRC 100\% mark, its arguments in large part turn on the economic benefits, especially in recruiting talented employees. And this is as it should be. It is wrong to think that "corporate morality" is an oxymoron, but it is naïve to think that all moral arguments must scrupulously ignore their impact on a decisionmaker's profitability.

\section{Closeting Equality}

A final concern about the mark is that it will not only commodify civil rights norms, but also privatize the norms in ways that set back the larger cause. Gay, lesbian, and bisexual people, as well as gay rights scholars, know well the dangers of the closet. Or the animus that can drive this demand: "We don't care what gay people do in the privacy of their own bedrooms, just don't ask us to recognize them in the public sphere." Critics could complain that the mark responds to an analogous (and equally problematic) demand: "We don't care what you companies do for gay people in the privacy of your own boardroom, just don't ask us to recognize it in the public sphere." Instead of framing nondiscrimination as a public value, the mark may contribute to a reconceptualization of it as merely a private choice upon which the government should not tread. 
Although worthy of consideration, this closeting concern is unlikely to arise. The adoption of the mark is itself a public act. While we allow licensees to practice the mark selectively, we as licensors-much like HRC with regard to corporate endorsers of ENDA-will maintain on the Internet a public database of adopters. ${ }^{151}$ Revealing the complete list of adopters also reveals those employers that have not adopted. So both the adoption and non-adoption of the mark become common knowledge. While a corporation could respond that the contours of its employment promises are private, the social meaning of certification marks is necessarily public.

And as argued earlier, the likely impact of private adoptions is to increase the demand for public mandates. The net result is that massive licensing of the mark would not denigrate equality to merely a private corporate choice shielded from public purview. Instead, nondiscrimination in the shadow of many adoptions would increasingly fuel demands for universal, mandatory norms.

\section{CONCLUSION}

This Article strives to do more than show the possibility of privatizing ENDA. It is performative as well. The Fair Employment mark now exists and is open for business. The licensing agreement in the Appendix can be copied, signed, and faxed to us by any employer and it will immediately take effect. (The signed and completed agreement can be faxed to Ian Ayres at 203-432-4769.) Or employers can go to www.fairemploymentmark.org and license the mark with just a few clicks of the mouse. With the publication of this Article, we hereby announce a formal licensing campaign. We intend to take the descriptive theory of Part III and use it to target employers that are more likely to be willing to adopt the mark. We hope within a year and a half to have 100,000 workers covered.

Although this Article has been a sustained attempt at defending and explicating the feasibility of the Fair Employment mark as a specific means of privatizing ENDA, the Article in a broader sense is a call for more explicit contracting. The earlier movement for non-binding policies was itself a useful form of incrementalism. Even these non-binding or probabilisticallybinding policies signaled the employer's viewpoint that homosexuality was not malum in se. The policies at a minimum conveyed the employer's aspiration. These mere words strongly suggested that one's sexual orientation would not be per se disqualifying. At the very least, they allowed the possibility of nonlegal enforcement. An employer that included sexual orientation in its nondiscrimination policy but nonetheless countenanced blatant discrimination might be publicly ridiculed. But the time to take the next incremental step is now.

Instead of asking for nondiscrimination policies, we should begin asking for nondiscrimination promises. We should demand more than hortatory claims of nondiscrimination. If nondiscrimination means anything, it should

151. See Human Rights Campaign Foundation, supra note 45 . 
mean that an employer legally commits not to engage in disparate treatment. The current policies are too close to "cheap talk" that can actually border on fraud. An applicant can read the pretty words of nondiscrimination and then be surprised to learn that, since she was never in privity with the employer, she has no cause of action. Our claim is simply that these nondiscrimination rights should now have legal remedies.

The next time you are at a meeting and you hear your own employer extol its nondiscrimination policy, you should speak up and ask, "Are you promising not to discriminate?" We are not posing a hypothetical. We call upon our academic readers to challenge their deans and university presidents (as well as the nonprofit boards on which they sit): "Is this institution willing to promise not to discriminate?" What are they going to say in response? "We take our nondiscrimination policy very seriously, but no, we're not willing to promise not to discriminate on the basis of sexual orientation."152 We are about to have a test - and you, gentle reader, are one of the subjects.

152. As we script this conversation, we might suggest you make this retort: "And would you opt out of Title VII generally, given the chance?" 


\section{APPENDIX \\ Licensing AgreEmEnt for the FAIR EMPLOYMENT MARK}

This AGREEMENT is made by and between:

Ian Ayres \& Jennifer Gerarda Brown, individuals residing in New Haven, CT (hereinafter "Licensor"), and [please insert name of employer/firm] (hereinafter "Licensee"),

WHEREAS, Licensor has devised a Fair Employment Mark (hereinafter "the Mark"), a copy of which is attached as Attachment A to this agreement, and has developed goodwill associated with the Mark and the names "Fair Employment Mark," and "fairemploymentmark.org."

WHEREAS, Licensee and Licensor desire to enter into an agreement pertaining to the Mark whereby Licensee shall have the right to use the Mark;

WHEREAS Licensee desires to privately commit to non-discrimination as defined in the Employment Non-Discrimination Act (ENDA) as proposed in S. $1705,108^{\text {th }}$ Cong., $1^{\text {st }}$ Sess. (2003), which is attached as Attachment B to this agreement.

NOW, THEREFORE, in consideration of the mutual agreements contained herein and for other good and valuable consideration, the receipt and sufficiency of which is hereby acknowledged, Licensor and Licensee agree as follows:

1. GRANT OF LICENSE. Licensor hereby grants to Licensee a license to use the Mark and all goodwill associated therewith as embodied by the term "the Mark", including, but not limited to, using the Mark in $\mathrm{Li}^{-}$ censee's products, services, and advertising materials.

2. TERM. The term of the license herein granted shall be five years ("the Term"), and renewed automatically upon for another five years at the end of every previous Term unless otherwise terminated by either party as set forth in Paragraph 13.

3. CONSIDERATION. In exchange for Licensor licensing the Mark to Licensee, Licensee promises to abide by the standards of fair employment defined in the next paragraph.

4. STANDARDS OF FAIR EMPLOYMENT. Licensee promises not to engage in the following employment practices:

(1) "to fail or refuse to hire or to discharge any individual, or otherwise to discriminate against any individual with respect to the compensation, 
terms, conditions, or privileges of employment of the individual, because of such individual's sexual orientation;" ENDA, S. 1705, § 4(a)(1) (attached hereto) or

(2) "to limit, segregate, or classify the employees or applicants for employment of the employer in any way that would deprive or tend to deprive any individual of employment or otherwise adversely affect the status of the individual as an employee, because of such individual's sexual orientation;" ENDA, S. 1705, §4 (a)(2) (attached hereto)

(3) to discriminate against any individual because of the sexual orientation of the individual "in admission to, or employment in, any program established to provide apprenticeship or other training;" ENDA, S. $1705, \S 4(\mathrm{~d})$ (attached hereto)

(4) to discriminate against an individual because such individual opposed any of the employment practices described in subsections (1) through (3), "or because such individual made a charge, testified, assisted, or participated in any manner in an investigation, proceeding, or hearing" concerned with this License. ENDA, S. 1705, \$5 (attached hereto)

The employment practices described in any of subsections (1) through (3) "shall be considered to include an action described in that subsection, taken against an individual based on the sexual orientation of a person with whom the individual associates or has associated." ENDA, S. 1705, $\$ 4$ (e) (attached hereto)

5. THIRD-PARTY BENEFICIARIES. Licensee and Licensor agree to designate as express third-party beneficiaries of this agreement all persons and entities that would be entitled to sue if ENDA were in effect (including governmental civil rights enforcement agencies). In particular, Licensee and Licensor designate as express third-party beneficiaries all persons who are or have been employed by the Licensee or applied for employment with the Licensee during the term of the license. The Licensee and Licensor intend that these third-party beneficiaries will have the right to sue the Licensee for any breach of this agreement and have a legal right to the same remedies (including damages and injunctive relief) to which they would be entitled if ENDA were in effect.

6. DISPARATE IMPACT AND AFFIRMATIVE ACTION. Disparate impact claims may not be brought under this License agreement. The Licensee by signing this agreement does not promise to engage in affirmative action on the basis of sexual orientation, and affirmative action for a breach of this agreement may not be imposed. See ENDA, S. 1705, $\S 4(f), 12(d)$ (attached hereto) 
7. BENEFITS. This License shall not be construed to require the provision of employee benefits to an individual for the benefit of the domestic partner of such individual.

8. COOPERATION. In exchange for the license granted herein, Licensee agrees to cooperate reasonably with the Licensor's requests for materials useful to Licensor in maintenance and renewal of the Mark, including but not limited to, specimens of use of the Mark in connection with Licensee's offering of goods and services, and lists of goods and services offered by the Licensee in connection with the Mark.

9. OWNERSHIP OF THE MARK. Licensee acknowledges that Licensor is the owner of the Mark and that all of Licensee's use of the Mark and any goodwill established in association with Licensee's use of the Mark shall inure to the benefit of Licensor. Apart from actions of fraud, misrepresentation and the like, Licensee shall not contest or deny the ownership or validity of the Mark or the title of the Licensor thereto.

10. LIMITED WARRANTY. Licensor hereby warrants that it has no actual knowledge of any trademark, service mark, collective mark or certification mark rights of any third-party which would impair Licensee's use of the Mark. Licensor further warrants that it has no actual knowledge of any adversarial proceeding or other license concerning the Mark. Licensor does not warrant that the Mark is a valid certification mark recognized by the U.S. Patent and Trademark Office.

11. CERTIFICATION. Licensor does not certify that Licensee in fact abides by the Standards of Fair Employment. But Licensor certifies that Licensee by signing this agreement (1) has promised to abide by the Standards of Fair Employment and (2) has granted third-party beneficiary rights to the individuals and entities enumerated above to enforce breaches of the Licensee's promise to abide by the Standards of Fair Employment. 
12. INFRINGEMENT BY THIRD PARTIES. The parties acknowledge their joint interest and obligation in policing the Mark and of notifying the other in the event that any potential infringement is found. Specifically, Licensee and Licensor agree promptly to give notice to the other of any infringement of the Mark or any threatened litigation or proceeding involving the Mark. Licensor shall not be obliged to take any action whatsoever against third parties who are infringing or believed to be infringing the Mark except as Licensor, in its sole discretion, shall deem advisable. Any action taken by Licensor on its own initiative shall be solely within its discretion, control and expense. If Licensee makes a written request to Licensor to take action against an alleged third-party infringer, Licensor may, in its discretion, elect not to take any action against such third-party infringer. In this event, or if Licensor does not respond to the aforementioned written request in seven (7) days, Licensee, at its sole cost, control, discretion and expense, shall be free to undertake any action against such a third-party infringer. In such an event, Licensee shall have the right to select its own counsel and Licensee shall keep Licensor completely informed of all developments. Except as set forth above, Licensee shall not institute any legal or administrative proceeding against any third-party with respect to the Mark without the prior written consent of Licensor. Licensor and Licensee may agree to permit themselves to be named in any adversarial action reasonably required to police and protect the Mark. In the event that Licensor does agree to participate in an adversarial proceeding instituted by the Licensee, the Licensee shall indemnify the Licensor. Licensor and Licensee agree to cooperate fully with the other in any defense or assertion of rights associated with the Mark.

13. TERMINATION. The Licensee for any reason can immediately terminate this agreement prior to the normal expiration of the Term by sending a written notice of termination by mail to the Licensor. The $\mathrm{Li}$ censor can terminate this agreement prior to the normal expiration of the Term if the Licensee shall be in breach of any material obligation set forth herein. Termination by the Licensor shall be effected by delivery of notice to the Licensee which notice expressly and in detail sets forth the basis for termination. This Agreement will terminate sixty (60) days after the Licensor shall send by mail notice of termination.

14. ENFORCEMENT. The Licensor waives any and all rights to sue Licensee for violation of the Standards of Fair Employment, but retains the right to sue the Licensee for unauthorized use of the Mark (including use of the Mark after termination of the license). Third-party beneficiaries have the exclusive rights to sue the Licensee for violation of the Standards of Fair Employment. Any lawsuit by a third-party beneficiary for violation of the Standards of Fair Employment shall be filed within one hundred and eighty days after the alleged violating employment practice occurred. 
15. REMEDIES. The remedies applicable to a claim alleged by a thirdparty beneficiary for a violation of the Standards of Fair Employment shall include all "remedies applicable for a violation of title VII of the Civil Rights Act of 1964 (42 U.S.C. 2000e et seq.)." ENDA S. 1705, $\$ 12(b)(1)$ (attached hereto). All specific remedies provided for in this Agreement shall be cumulative and shall not be exclusive of one another or of any other remedies available in law or in equity. The failure to insist upon strict performance of any of the covenants or terms hereof to be performed shall not be construed as a waiver of such covenants or terms. Should either the Licensee or the Licensor file litigation against the other party to enforce the terms of this Agreement, then the nonbreaching party in such litigation as determined by a final, nonappealable order of a court of competent jurisdiction shall be entitled to receive from the breaching party all of its costs and expenses in such litigation including reasonable attorneys' fees.

16. ENTIRE AGREEMENT. This Agreement constitutes the entire agreement between the parties solely with respect to the licensing of the Mark. The Agreement supersedes any prior agreements or understandings, whether written or oral, between or among the parties regarding the licensing of the Mark. The parties agree that this Agreement may not be amended or changed in any way except by written instruments signed by each of the parties hereto.

17. CHOICE OF LAW AND FORUM. Except to the extent governed by the Lanham Act (15 U.S.C. $\S \S 1051$ et seq.), this Agreement shall be interpreted and construed pursuant to the law of the State of Connecticut without regard to its conflict of laws. The Standards of Fair Employment of this license shall be interpreted in cases of ambiguity to impose the same duties on the Licensor as would apply if the version of ENDA attached as Attachment B had been enacted by Congress and was in force. Any lawsuit filed in connection with this Agreement by either licensor or licensee against the other shall be in a court located in the State of Connecticut. Any lawsuit filed in connect with this Agreement by a third-party beneficiary shall be in a court located in the state where the alleged violation of the Standards of Fair Employment occurred.

18. ASSIGNMENTS AND BINDING EFFECT. Licensee shall not directly or indirectly assign, sub-license, pledge, encumber, grant or otherwise transfer any of its rights conferred by this Agreement. This Agreement shall be binding upon and inure to the benefit of each of the parties hereto and each of their respective authorized purchasers, successors and assigns.

19. WAIVER. The waiver by any party of a breach or provision of this Agreement shall not operate or be construed as a waiver of any subsequent breach by such other party. 
20. SEVERABILITY. If any provision of this Agreement is held to be illegal, invalid, or unenforceable under any law, rule, or regulation, such provision shall be fully severable and this Agreement shall be construed and enforced as if such illegal, invalid, or unenforceable provision never comprised a part hereof. The remaining provisions of this Agreement shall remain in full force and effect, and shall not be affected by the illegal, invalid, or unenforceable provision or by its severance herefrom.

21. RECITALS AND HEADINGS. The recitals contained in this Agreement are an integral part hereof and this Agreement shall be construed in light of such recitals. The captions and headings contained herein are for convenient reference only and shall not be construed as a part hereof.

22. COUNTERPART AGREEMENTS. This Agreement may be executed by each of the parties in separate counterpart and have the same force and effect as if it had been executed as a single document.

23. NOTICE. Any notice or other communication required, contemplated or permitted under the terms of this Agreement must be given in writing by U.S. post or by overnight courier such as DHL, Federal Express, or Express Mail. Notice shall be deemed effective on the date sent. All notices or formal communications pursuant to this Agreement shall be sent to the parties as follows: 
To Licensor: $\quad$ Ian Ayres \& Jennifer Gerarda Brown

127 Wall Street

New Haven, CT 06511

To Licensee:

[insert name and mailing address]

IN WITNESS WHEREOF, the parties have executed this Agreement by and through their properly authorized signatories effective as of the date indicated above.

Licensor Signatures:

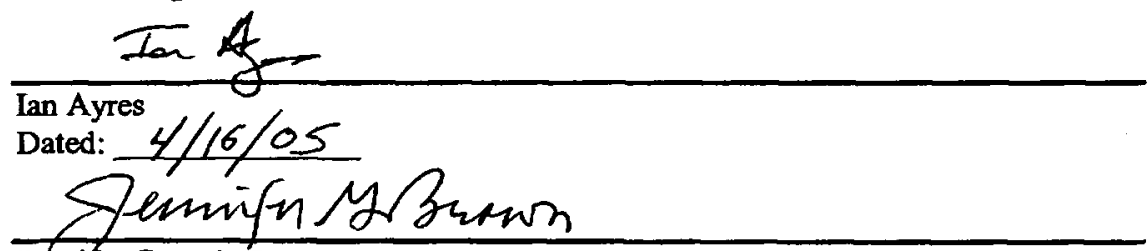

Jegnifer Gerarda Brown

Dated: $4 / 16 / 05$

Licensee Signature:

[authorized signature]

[print name]

[print title]

Dated:

Approximate number of employees currently employed by Licensee:

Please fax the completed and signed agreement to Ian Ayres at (203) 4324769. 


\section{AtTAChment A}

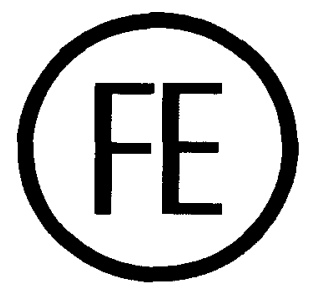


ATTACHMENT B

108th CONGRESS

1.1st Session

S. 1705

To prohibit employment discrimination on the basis of sexual orientation.

\section{IN THE SENATE OF THE UNITED STATES}

\section{October 2, 2003}

Mr. KENNEDY (for himself, Mr. JEFFORDS, Mr. CHAFEE, Mr. LIEBERMAN, Mr. AKAKA, Mr. BAUCUS, Mr. BAYH, Mr. BIDEN, Mr. BINGAMAN, Mrs. BOXER, Mr. BREAUX, Ms. CANTWELL, Mr. CARPER, Mrs. CLINTON, Ms. COLLINS, Mr. CORZINE, Mr. DASCHLE, Mr. DAYTON, Mr. DODD, Mr. DORGAN, Mr. DURBIN, Mr. EDWARDS, Mr. FEINGOLD, Mrs. FEINSTEIN, Mr. GRAHAM of Florida, Mr. HARKIN, Mr. INOUYE, Mr. KERRY, Mr. KOHL, Ms. LANDRIEU, Mr. LAUTENBERG, Mr. LEAHY, Mr. LEVIN, Ms. MIKULSKI, Mrs. MURRAY, Mr. NELSON of Florida, Mr. REED, Mr. REID, Mr. SARBANES, Mr. SCHUMER, Mr. SMITH, Mr. SPECTER, Ms. STABENOW, and Mr. WYDEN) introduced the following bill; which was read twice and referred to the Committee on Health, Education, Labor, and Pensions

\section{A BILL}

To prohibit employment discrimination on the basis of sexual orientation.

$B e$ it enacted by the Senate and House of Representatives of the United States of America in Congress assembled,

\section{SECTION 1. SHORT TITLE.}

This Act may be cited as the 'Employment Non-Discrimination Act of 2003'.

\section{SEC. 2. PURPOSES.}

The purposes of this Act are--

(1) to provide a comprehensive Federal prohibition of employment discrimination on the basis of sexual orientation;

(2) to provide meaningful and effective remedies for employment discrimination on the basis of sexual orientation; and

(3) to invoke congressional powers, including the powers to 
enforce the 14th amendment to the Constitution, and to regulate interstate commerce and provide for the general welfare pursuant to section 8 of article I of the Constitution, in order to prohibit employment discrimination on the basis of sexual orientation.

\section{SEC. 3. DEFINITIONS.}

(a) IN GENERAL- In this Act:

(1) COMMISSION- The term 'Commission' means the Equal Employment Opportunity Commission.

(2) COVERED ENTITY- The term 'covered entity' means an employer, employment agency, labor organization, or joint labormanagement committee.

\section{(3) EMPLOYEE-}

(A) IN GENERAL- The term 'employee' means--

(i) an employee (as defined in section 701(f) of the Civil Rights Act of 1964 (42 U.S.C. $2000 \mathrm{e}(\mathrm{f})$ );

(ii) a Presidential appointee or State employee to which section 302(a)(1) of the Government Employee Rights Act of 1991 (42 U.S.C. 2000e-16b(a)(1)) applies;

(iii) a covered employee, as defined in section 101 of the Congressional Accountability Act of 1995 (2 U.S.C. 1301) or section 411(c) of title 3 , United States Code; or

(iv) an employee or applicant to which section 717(a) of the Civil Rights Act of 1964 (42 U.S.C. 2000e-16(a)) applies.

(B) EXCEPTION- The provisions of this Act that apply to an employee or individual shall not apply to a volunteer who receives no compensation.

(4) EMPLOYER- The term 'employer' means--

(A) a person engaged in an industry affecting commerce (as defined in section 701(h) of the Civil Rights Act of 1964 (42 U.S.C. $2000 \mathrm{e}(\mathrm{h})$ ) who has 15 or more employees (as defined in subparagraphs (A)(i) and (B) of paragraph (3)) for each working day in each of 20 or more calendar weeks in the current or preceding calendar year, and any agent of such a person, but does not include a bona fide private membership club (other than 
a labor organization) that is exempt from taxation under section 501(c) of the Internal Revenue Code of 1986;

(B) an employing authority to which section 302(a)(1) of the Government Employee Rights Act of 1991 applies;

(C) an employing office, as defined in section 101 of the Congressional Accountability Act of 1995 or section 411(c) of title 3, United States Code; or

(D) an entity to which section 717(a) of the Civil Rights Act of 1964 applies.

(5) EMPLOYMENT AGENCY- The term 'employment agency' has the meaning given the term in section 701(c) of the Civil Rights Act of 1964 (42 U.S.C. 2000e(c)).

(6) LABOR ORGANIZATION- The term 'labor organization' has the meaning given the term in section 701(d) of the Civil Rights Act of 1964 (42 U.S.C. 2000e(d)).

(7) PERSON- The term 'person' has the meaning given the term in section 701(a) of the Civil Rights Act of 1964 (42 U.S.C. 2000e(a)).

(8) RELIGIOUS ORGANIZATION- The term 'religious organization' means--

(A) a religious corporation, association, or society; or

(B) a school, college, university, or other educational institution or institution of learning, if--

(i) the institution is in whole or substantial part controlled, managed, owned, or supported by a religion, religious corporation, association, or society; or

(ii) the curriculum of the institution is directed toward the propagation of a religion.

(9) SEXUAL ORIENTATION- The term 'sexual orientation' means homosexuality, bisexuality, or heterosexuality, whether the orientation is real or perceived.

(10) STATE- The term 'State' has the meaning given the term in section 701(i) of the Civil Rights Act of 1964 (42 U.S.C. 2000e(i)).

(b) APPLICATION OF DEFINITIONS- For purposes of this section, a reference in section 701 of the Civil Rights Act of 1964-- 
(1) to an employee or an employer shall be considered to refer to an employee (as defined in paragraph (3)) or an employer (as defined in paragraph (4)), respectively, except as provided in paragraph (2); and

(2) to an employer in subsection (f) of that section shall be considered to refer to an employer (as defined in paragraph (4)(A)).

\section{SEC. 4. DISCRIMINATION PROHIBITED.}

(a) EMPLOYER PRACTICES-It shall be an unlawful employment practice for an employer--

(1) to fail or refuse to hire or to discharge any individual, or otherwise to discriminate against any individual with respect to the compensation, terms, conditions, or privileges of employment of the individual, because of such individual's sexual orientation; or

(2) to limit, segregate, or classify the employees or applicants for employment of the employer in any way that would deprive or tend to deprive any individual of employment or otherwise adversely affect the status of the individual as an employee, because of such individual's sexual orientation.

(b) EMPLOYMENT AGENCY PRACTICES- It shall be an unlawful employment practice for an employment agency to fail or refuse to refer for employment, or otherwise to discriminate against, any individual because of the sexual orientation of the individual or to classify or refer for employment any individual on the basis of the sexual orientation of the individual.

(c) LABOR ORGANIZATION PRACTICES- It shall be an unlawful employment practice for a labor organization--

(1) to exclude or to expel from its membership, or otherwise to discriminate against, any individual because of the sexual orientation of the individual;

(2) to limit, segregate, or classify its membership or applicants for membership, or to classify or fail or refuse to refer for employment any individual, in any way that would deprive or tend to deprive any individual of employment, or would limit such employment or otherwise adversely affect the status of the individual as an employee or as an applicant for employment, because of such individual's sexual orientation; or

(3) to cause or attempt to cause an employer to discriminate against an individual in violation of this section.

(d) TRAINING PROGRAMS- It shall be an unlawful employment practice for any employer, labor organization, or joint labor-management committee controlling apprenticeship or other training or retraining, in- 
cluding on-the-job training programs, to discriminate against any individual because of the sexual orientation of the individual in admission to, or employment in, any program established to provide apprenticeship or other training.

(e) ASSOCIATION- An unlawful employment practice described in any of subsections (a) through (d) shall be considered to include an action described in that subsection, taken against an individual based on the sexual orientation of a person with whom the individual associates or has associated.

(f) DISPARATE IMPACT- Only disparate treatment claims may be brought under this Act.

\section{SEC. 5. RETALIATION PROHIBITED.}

It shall be an unlawful employment practice for a covered entity to discriminate against an individual because such individual opposed any practice made an unlawful employment practice by this Act, or because such individual made a charge, testified, assisted, or participated in any manner in an investigation, proceeding, or hearing under this Act.

\section{SEC. 6. BENEFITS.}

This Act does not apply to the provision of employee benefits to an individual for the benefit of the domestic partner of such individual.

\section{SEC. 7. COLLECTION OF STATISTICS PROHIBITED.}

The Commission shall not collect statistics on sexual orientation from covered entities, or compel the collection of such statistics by covered entities.

\section{SEC. 8. QUOTAS AND PREFERENTIAL TREATMENT PROHIBITED.}

(a) QUOTAS- A covered entity shall not adopt or implement a quota on the basis of sexual orientation.

(b) PREFERENTIAL TREATMENT- A covered entity shall not give preferential treatment to an individual on the basis of sexual orientation.

(c) ORDERS AND CONSENT DECREES- Notwithstanding any other provision of this Act, an order or consent decree entered for a violation of this Act may not include a quota, or preferential treatment to an individual, based on sexual orientation.

\section{SEC. 9. RELIGIOUS EXEMPTION.}

This Act shall not apply to a religious organization. 


\section{SEC. 10. NONAPPLICATION TO MEMBERS OF THE ARMED FORCES; VETERANS' PREFERENCES.}

(a) ARMED FORCES-

(1) EMPLOYMENT- In this Act, the term 'employment' does not apply to the relationship between the United States and members of the Armed Forces.

(2) ARMED FORCES- In paragraph (1), the term 'Armed Forces' means the Army, Navy, Air Force, Marine Corps, and Coast Guard.

(b) VETERANS' PREFERENCES- This Act does not repeal or modify any Federal, State, territorial, or local law creating a special right or preference concerning employment for a veteran.

\section{SEC. 11. CONSTRUCTION.}

(a) EMPLOYER RULES AND POLICIES- Nothing in this Act shall be construed to prohibit a covered entity from enforcing rules and policies, if the rules or policies are designed for, and uniformly applied to, all individuals regardless of sexual orientation.

(b) ASSOCIATION- Nothing in this Act shall be construed to prohibit any association, or infringe upon any right of association, guaranteed by the first amendment

to the Constitution, of any nonprofit, voluntary membership organization.

\section{SEC. 12. ENFORCEMENT.}

(a) ENFORCEMENT POWERS- With respect to the administration and enforcement of this Act in the case of a claim alleged by an individual for a violation of this Act--

(1) the Commission shall have the same powers as the Commission has to administer and enforce--

(A) title VII of the Civil Rights Act of 1964 (42 U.S.C. $2000 \mathrm{e}$ et seq.); or

(B) sections 302 and 304 of the Government Employee Rights Act of 1991 (42 U.S.C. 2000e-16b and 2000e$16 c)$;

in the case of a claim alleged by such individual for a violation of such title, or of section 302(a)(1) of the Government Employee Rights Act of 1991 (42 U.S.C. 2000e-16b(a)(1)), respectively;

(2) the Librarian of Congress shall have the same powers as the 
Librarian of Congress has to administer and enforce title VII of the Civil Rights Act of 1964 (42 U.S.C. 2000e et seq.) in the case of a claim alleged by such individual for a violation of such title;

(3) the Board (as defined in section 101 of the Congressional Accountability Act of 1995 (2 U.S.C. 1301)) shall have the same powers as the Board has to administer and enforce the Congressional Accountability Act of 1995 (2 U.S.C. 1301 et seq.) in the case of a claim alleged by such individual for a violation of section 201(a)(1) of such Act (2 U.S.C. 1311(a)(1));

(4) the Attorney General shall have the same powers as the Attorney General has to administer and enforce--

(A) title VII of the Civil Rights Act of 1964 (42 U.S.C. 2000 e et seq.); or

(B) sections 302 and 304 of the Government Employee Rights Act of 1991 (42 U.S.C. 2000e-16b and 2000e$16 \mathrm{c})$;

in the case of a claim alleged by such individual for a violation of such title, or of section 302(a)(1) of the Government Employee Rights Act of 1991 (42 U.S.C. 2000e-16b(a)(1)), respectively;

(5) the President, the Commission, and the Merit Systems Protection Board shall have the same powers as the President, the Commission, and the Board, respectively, have to administer and enforce chapter 5 of title 3, United States Code, in the case of a claim alleged by such individual for a violation of section 411 of such title;

(6) a court of the United States shall have the same jurisdiction and powers as the court has to enforce--

(A) title VII of the Civil Rights Act of 1964 (42 U.S.C. $2000 \mathrm{e}$ et seq.) in the case of a claim alleged by such individual for a violation of such title;

(B) sections 302 and 304 of the Government Employee Rights Act of 1991 (42 U.S.C. 2000e-16b and 2000e$16 \mathrm{c})$ in the case of a claim alleged by such individual for a violation of section 302(a)(1) of such Act (42 U.S.C. 2000e-16b(a)(1));

(C) the Congressional Accountability Act of 1995 (2 U.S.C. 1301 et seq.) in the case of a claim alleged by such individual for a violation of section 201(a)(1) of such Act (2 U.S.C. 1311(a)(1)); and

(D) chapter 5 of title 3, United States Code, in the case 
of a claim alleged by such individual for a violation of section 411 of such title.

(b) PROCEDURES AND REMEDIES- The procedures and remedies applicable to a claim alleged by an individual for a violation of this Act are--

(1) the procedures and remedies applicable for a violation of title VII of the Civil Rights Act of 1964 (42 U.S.C. 2000e et seq.) in the case of a claim alleged by such individual for a violation of such title;

(2) the procedures and remedies applicable for a violation of section 302(a)(1) of the Government Employee Rights Act of 1991 (42 U.S.C. $2000 \mathrm{e}-16 \mathrm{~b}(\mathrm{a})(1))$ in the case of a claim alleged by such individual for a violation of such section;

(3) the procedures and remedies applicable for a violation of section 201(a)(1) of the Congressional Accountability Act of 1995 (2 U.S.C. 1311(a)(1)) in the case of a claim alleged by such individual for a violation of such section; and

(4) the procedures and remedies applicable for a violation of section 411 of title 3 , United States Code, in the case of a claim alleged by such individual for a violation of such section.

(c) OTHER APPLICABLE PROVISIONS- With respect to a claim alleged by a covered employee (as defined in section 101 of the Congressional Accountability Act of

1995 (2 U.S.C. 1301)) for a violation of this Act, title III of the Congressional Accountability Act of 1995 (2 U.S.C. 1381 et seq.) shall apply in the same manner as such title applies with respect to a claim alleged by such a covered employee for a violation of section 201(a)(1) of such Act (2 U.S.C. 1311(a)(1)).

(d) PROHIBITION OF AFFIRMATIVE ACTION- Notwithstanding any other provision of this section, affirmative action for a violation of this Act may not be imposed. Nothing in this section shall prevent the granting of relief to any individual who suffers a violation of such individual's rights provided in this Act.

\section{SEC. 13. STATE AND FEDERAL IMMUNITY.}

(a) STATE IMMUNITY- A State shall not be immune under the 11th amendment to the Constitution from a suit described in subsection (b) and brought in a Federal court of competent jurisdiction for a violation of this Act.

(b) REMEDIES FOR STATE EMPLOYEES-

(1) IN GENERAL- 
(A) WAIVER- A State's receipt or use of Federal financial assistance for any program or activity of a State shall constitute a waiver of sovereign immunity, under the 11th amendment to the Constitution or otherwise, to a suit brought by an employee or applicant for employment of that program or activity under this Act for a remedy authorized under subsection (c).

(B) DEFINITION- In this paragraph, the term 'program or activity' has the meaning given the term in section 606 of the Civil Rights Act of 1964 (42 U.S.C. 2000d$4 a)$.

(2) OFFICIALS- An official of a State may be sued in the official capacity of the official by any employee or applicant for employment who has complied with the applicable procedures of section 12, for equitable relief that is authorized under this Act. In such a suit the court may award to the prevailing party those costs authorized by section 722 of the Revised Statutes (42 U.S.C. 1988).

(3) EFFECTIVE DATE- With respect to a particular program or activity, paragraphs (1) and (2) apply to conduct occurring on or after the day, after the date of enactment of this Act, on which a State first receives or uses Federal financial assistance for that program or activity.

(c) REMEDIES AGAINST THE UNITED STATES AND THE STATESNotwithstanding any other provision of this Act, in an action or administrative proceeding against the United States or a State for a violation of this Act, remedies (including remedies at law and in equity, and interest) are available for the violation to the same extent as the remedies are available for a violation of title VII of the Civil Rights Act of 1964 (42 U.S.C. 2000 e et seq.) by a private entity, except that--

(1) punitive damages are not available; and

(2) compensatory damages are available to the extent specified in section 1977A(b) of the Revised Statutes (42 U.S.C. 1981a(b)).

\section{SEC. 14. ATTORNEYS' FEES.}

Notwithstanding any other provision of this Act, in an action or administrative proceeding for a violation of this Act, an entity described in section 12(a) (other than paragraph (4) of such section), in the discretion of the entity, may allow the prevailing party, other than the Commission or the United States, a reasonable attorney's fee (including expert fees) as part of the costs. The Commission and the United States shall be liable for the costs to the same extent as a private person. 


\section{SEC. 15. POSTING NOTICES.}

A covered entity who is required to post notices described in section 711 of the Civil Rights Act of 1964 (42 U.S.C. 2000e-10) shall post notices for employees, applicants for employment, and members, to whom the provisions specified in section 12(b) apply, that describe the applicable provisions of this Act in the manner prescribed by, and subject to the penalty provided under, section 711 of the Civil Rights Act of 1964.

\section{SEC. 16. REGULATIONS.}

(a) IN GENERAL- Except as provided in subsections (b), (c), and (d), the Commission shall have authority to issue regulations to carry out this Act.

(b) LIBRARIAN OF CONGRESS- The Librarian of Congress shall have authority to issue regulations to carry out this Act with respect to employees and applicants for employment of the Library of Congress.

(c) BOARD- The Board referred to in section 12(a)(3) shall have authority to issue regulations to carry out this Act, in accordance with section 304 of the Congressional Accountability Act of 1995 (2 U.S.C. 1384), with respect to covered employees, as defined in section 101 of such Act (2 U.S.C. 1301).

(d) PRESIDENT- The President shall have authority to issue regulations to carry out this Act with respect to covered employees, as defined in section 411(c) of title 3, United States Code.

\section{SEC. 17. RELATIONSHIP TO OTHER LAWS.}

This Act shall not invalidate or limit the rights, remedies, or procedures available to an individual claiming discrimination prohibited under any other Federal law or any law of a State or political subdivision of a State.

\section{SEC. 18. SEVERABLITY.}

If any provision of this Act, or the application of the provision to any person or circumstance, is held to be invalid, the remainder of this Act and the application of the provision to any other person or circumstance shall not be affected by the invalidity.

\section{SEC. 19. EFFECTIVE DATE.}

This Act shall take effect 60 days after the date of enactment of this Act and shall not apply to conduct occurring before the effective date. 